\title{
The Use of Bacterial Polysaccharides in Bioprinting
}

Ronan R McCarthy ${ }^{1}{ }^{* \#}$, Muhammad Wajid Ullah ${ }^{2 \#}$, Peter Booth ${ }^{3}$, Eujin Pei ${ }^{3}$, Guang Yang ${ }^{2}$

${ }^{1}$ Division of Biosciences , Department of Life Sciences, College of Health and Life Sciences, Brunel University London, Uxbridge, UB8 3PH, UK

${ }^{2}$ Department of Biomedical Engineering, Huazhong University of Science and Technology, Wuhan 430074, PR China

${ }^{3}$ Department of Design, College of Engineering, Design and Physical Sciences, Brunel University London, Uxbridge, UB8 3PH, UK

${ }^{\#}$ These authors contributed equally to this work.

\section{*Correspondence}

Ronan R McCarthy

Email: ronan.mccarthy@brunel.ac.uk 


\begin{abstract}
Additive manufacturing or $3 \mathrm{D}$ printing has spearheaded a revolution in the biomedical sector allowing the rapid prototyping of medical devices. The recent advancements in bioprinting technology are enabling the development of potential new therapeutic options with respect to tissue engineering and regenerative medicines. Bacterial polysaccharides have been shown to be a central component of the inks used in a variety of bioprinting processes influencing their key features such as the mechanical and thermal properties, printability, biocompatibility, and biodegradability. However, the implantation of any foreign structure in the body comes with an increased risk of bacterial infection and immunogenicity. In recent years, this risk is being potentiated by the rise in nosocomial multidrug-resistant bacterial infections. Inks used in bioprinting are being augmented with antimicrobials to mitigate this risk. The applications of bacterial polysaccharide-based bioinks have the potential to act as a key battlefront in the war against antibiotic resistance. This paper reviews the range of bacterial polysaccharides used in bioprinting and discusses the potential of various bioactive polysaccharides to be integrated into these inks.
\end{abstract}

Keywords: Antimicrobial inks; Bacterial polysaccharides; Bioprinting; Tissue engineering; Biotherapeutics. 


\section{Introduction: Emergence of bioprinting technology}

Additive manufacturing or $3 \mathrm{D}$ printing is a rapidly emerging field that is being integrated into a wide variety of areas such as tissue engineering, regenerative medicines, aerospace engineering, and even property construction (Loh et al,, 2018; Shi et al., 2019; Zhang et al., 2019). The integration of bioscience and design has enabled the development of 3D biofabrication techniques that provide an assembly scaffold for tissue growth enhancement, and a means of incorporating cells and growth factors to encourage tissue generation (Derakhshanfar et al., 2018). The development of this bioprinting technology has facilitated treatments including wound dressings, bone repair, and the construction of responsive structures such as ear, liver, skin, neural tissues, and heart constructs (Aljohani et al, 2018b; Cornelissen et al., 2017). Several different 3D bioprinting technologies have been developed; the most popular include extrusion printing, droplet (inkjet) printing, laser-assisted printing, and stereolithography (Fig. 1). Extrusion-based printing (EBB) utilizes the mechanical or pneumatic dispensing of the bioink. Compared to other bioprinting technologies, EBB is able to generate the most structurally robust constructs. The viscosity of bioink is a key determining factor in this, as high resolution printing can be achieved with higher viscosity. Increasing the viscosity can also increase the risk of extrusion pressure and shear stress-induced cell mortality, however many functional hydrogels can be printed without increasing the shear stress and extrusion pressure to detrimental levels (Hölzl et al., 2016; Yi et al., 2017). EBB has the advantage of allowing the use of multiple print heads or precursor cartridges to extrude different bioinks increasing the capacity to print more complex human tissues (Kang et al, 2018; J. Li et al., 2016; Mandrycky et al., 2016). Dropletbased bioprinting (DBB) enables accurate ink deposition, with droplets generated by either thermal, piezoelectric, electrostatic, or drop techniques. The bioink droplet is generated by a 
short electric pulse to the heating element, forming a bubble to exude the ink droplet. Similarly, a charge is applied to piezo crystals in piezoelectric inkjets, and the resulting vibration forces the ink droplet out. Though fast and low cost, using high-density inks can result in clogged print nozzles which affects the droplet size and precision deposition (Gudapati et al., 2016). This issue has largely been addressed by using acoustic ejectors such as a piezoelectric actuator (Murphy and Atala, 2014). DBB is still widely used to print replicating narrow complex biological structures; although factors such as heat, vibration, and physical stress can induce cell mortality (Yi et al., 2017). Droplet-based bioprinters are relatively cheap and contamination can be easier to manage compared to other bioprinters. The use of multiple print heads can facilitate the production of complex multi-cell constructs (Xu et al., 2013). Laser-assisted bioprinting (LAB) guides an individual cell with a laser pulse from a donor source to a given surface. As the pulse creates a bubble, it forces the cells to transfer. The near UV wavelengths provide the energy to enable nozzle-free, high-resolution precision printing of biological structures, and the use of more viscous bioinks (Trombetta et al., 2017). Stereolithography polymerizes photo-sensitive polymers using a digital mirror projector array for a uniform print. It is one of the most accurate of the solid freeform techniques, printing at a high resolution $(100 \mu \mathrm{m})$ while maintaining high cell viability (Gou et al., 2014). Table 1 gives a comparative overview of different bioprinters in term of their cost, cell viability, printing speed, supported viscosities, resolution, quality of vertical structure, cell density, representative materials for bioinks, and the reported biomedical applications.. Bioprinting technologies are rapidly evolving yet; the search for suitable bioprinting materials remains a key limiting factor to the integration of these technologies to the biomedical sector. 
Table 1. A comparison of inkjet, laser-assisted, extrusion, and stereolithography printers. The table has been modified from (Mandrycky et al, 2016) with permission from Elsevier.

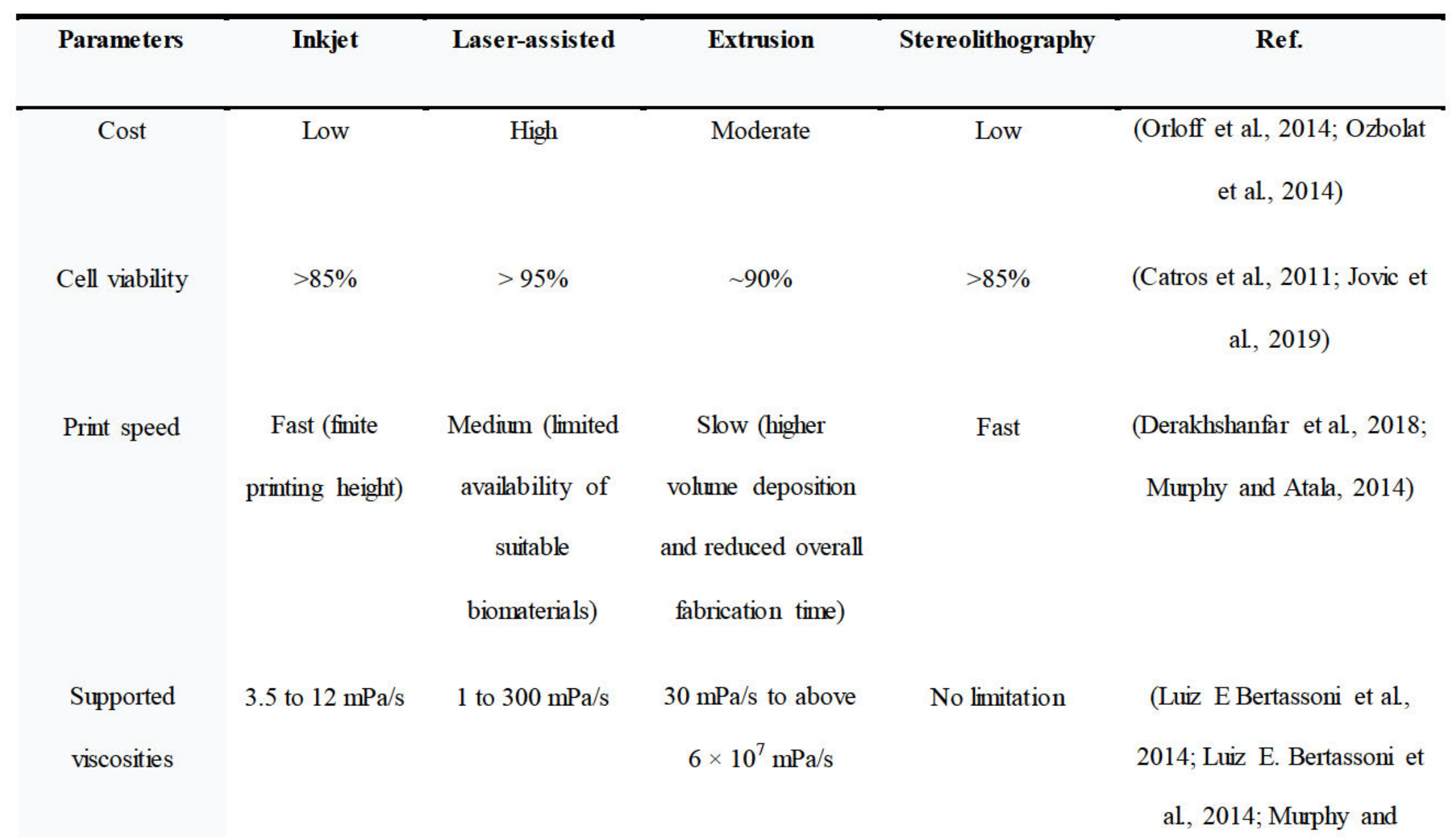




\begin{tabular}{|c|c|c|c|c|c|}
\hline Parameters & Inkjet & Laser-assisted & Extrusion & Stereolithography & Ref. \\
\hline & & & & & Atala, 2014) \\
\hline Resolution & High & High & Moderate & High & $\begin{array}{c}\text { (Ozbolat and } \mathrm{Yu}, 2013 ; \mathrm{Z} \text {. } \\
\text { Wang et al, 2015) }\end{array}$ \\
\hline $\begin{array}{c}\text { Quality of } \\
\text { vertical structure }\end{array}$ & Poor & Fair & Good & Good & (Z. Wang et al, 2015) \\
\hline Cell density & Low & Medium & High (inchuding & Medium & (Aljohani et al, 2018b; \\
\hline & $<10^{6}$ cells $/ \mathrm{mL}$ & $<10^{8}$ cells $/ \mathrm{mL}$ & $\begin{array}{l}\text { multicellular } \\
\text { spheroids) }\end{array}$ & $<10^{8}$ cells $/ \mathrm{mL}$ & Murphy and Atala, 2014) \\
\hline Representative & Alginate, & Collagen, & Alginate, & GeIMA, & (Kolesky et al, 2014; Z. \\
\hline materials for & PEGDMA, & Matrigel & GelMA, & GeIMA-PEGDA & Wang et al., 2015; Yu et al, \\
\hline bioinks & Collagen & & Collagen & hybrid hydrogel & 2014) \\
\hline Reported & $\begin{array}{l}\text { Tissue } \\
\text { engineering }\end{array}$ & $\begin{array}{c}\text { Tissue } \\
\text { engineering }\end{array}$ & $\begin{array}{l}\text { Tissue engineering } \\
\text { (blood vessel, bone, }\end{array}$ & $\begin{array}{l}\text { Tissue engineering } \\
\text { (blood vessel and }\end{array}$ & (Gou et al, 2014; Huang et \\
\hline
\end{tabular}




\begin{tabular}{|c|c|c|c|c|c|}
\hline Parameters & Inkjet & Laser-assisted & Extrusion & Stereolithography & Ref. \\
\hline applications & $\begin{array}{l}\text { (blood vessel, } \\
\text { bone, cartilage, } \\
\text { and neuron) }\end{array}$ & $\begin{array}{l}\text { (blood vessel, } \\
\text { bone, skin, and } \\
\text { adipose) }\end{array}$ & $\begin{array}{l}\text { cartilage, neuron, } \\
\text { muscle, tumor) } \\
\text { Controlled release } \\
\text { of } \\
\text { biomacromo lecules } \\
\text { Organ-on-a-chip }\end{array}$ & $\begin{array}{c}\text { cartilage) } \\
\text { Organ-on-a-chip }\end{array}$ & al, 2014; Park et al., 2018) \\
\hline
\end{tabular}


One of the principle issues associated with the insertion of any foreign object such as a bioprinted scaffold into the human body is the increased capacity for bacteria to attach to that object and establish a biofilm. Bacteria growing in biofilms have been shown to be $10-1,000$ fold more resistant to antibiotics than their planktonic counterparts (Römling and Balsalobre, 2012). Almost $80 \%$ of all hospitals-related bacterial infections involve biofilm formation (Pandin et al., 2017). A biofilm, by definition, is a structured community of bacterial cells enclosed in a self-produced polymeric matrix and adherent to an inert or living surface (Tshikantwa et al, 2018). The biofilm mode of growth offers protection from various environmental challenges such as the innate and the adaptive immune system as well as offering an increased tolerance to antimicrobial and disinfection agents. The annual cost for biofilm infections in the USA is estimated to be $\$ 94$ billion, with more than half a million deaths (Römling et al., 2014). The association of bacterial biofilms with non-native implanted structures is one of the leading concerns when it comes to the transition of bioprinting technologies from the benchtop to the clinic, particularly as individuals requiring bioprinted devices or organs may often already have a diminished immune capacity (J. Yue et al, 2015). The ability to mitigate this risk by using bioinks or ink-substrates that have the capacity to prevent bacterial growth or biofilm formation has the potential to be a viable strategy to overcome the risk of infection with device implantation. Hydrogels have emerged as one of the most promising bases for bioprinted inks, and many of the hydrogels used in bioprinting today are composed of bacterial polymers (Gopinathan and Noh, 2018; McCarthy et al., 2019). In this review, we will explore different bacterial-based polysaccharides that can be used as raw materials in bioprinting and highlight the range of bacterial-derived polysaccharides exhibiting antibacterial or anti-biofilm activities that could be used to potentially decrease the likelihood of infection on bioprinted structures. We will 
also explore the capacity for these polysaccharides to be impregnated with bioactive compounds to prevent bacterial adhesion and discuss the different areas of medicine that these bacterial polysaccharides can potentially impact. Identifying the right polysaccharide to utilize in a bioink can significantly influence the ultimate success of any fabricated structures using that particular substrate.

\section{Bacterial polymers}

Bacteria produce four primary classes of polymers: including polysaccharides, polyesters, polyamides, and inorganic polyanhydrides. Many of these polymers are secreted from the cell, with many forming the key matrix components of social structures such as biofilms. With respect to functionality, polysaccharides have demonstrated the highest capacity for integration into currently available printing technologies (Rehm, 2010) as these are stereoregular and can adopt an ordered conformation under given conditions. These polysaccharides can be divided into two groups based on the composition: homopolysaccharides composed of a single type of saccharide, and heteropolysaccharide consisting of multiple different saccharide species. Different subgroups within these classifications are defined by their chemical nature and different bonds linking the monomers comprising the polymer. These bacterial polymers can be further classified based on functionality such as sorptive (Gupta and Diwan, 2017), nutritive (Flemming and Wingender, 2001), immunostimulatory (McCarthy et al., 2017), redox-active (S. W. Li et al., 2016), communicative (Irie et al., 2017, 2012), and architectural (Powell et al., 2018). These properties need to be considered with respect to downstream functionality particularly when assessing the suitability of a bacterial polysaccharide to be utilized as an ink constituent for bioprinting. The location of a specific polysaccharide may also impact the potential functionality as bacterial polysaccharides can be intracellular, stored in the cytoplasm such as glycogen and 
bacterial starch or associated with the cell-surface such as peptidoglycan, lipopolysaccharides, lipooligosaccharides, teichoic acids, lipoteichoic acids, capsular polysaccharides (CPS) and exopolysaccharides (EPS) (Chapot-Chartier, 2014; Mistou et al., 2016; Tytgat and Lebeer, 2014). EPSs and CPSs differ in their degree of attachment to the cell surface: EPSs are loosely associated with the cell surface via electrostatic interactions and often form a slime layer, while the CPSs are tightly linked to the cell surface and form a capsule around the cell surface. EPSs serve as natural adhesive and protect the cells from environmental stresses such as extreme $\mathrm{pH}$, temperature, action of antibiotics, and desiccation. EPSs also play an essential role in the hostpathogen interaction and biofilm formation (Limoli et al., 2015; Schmid, 2018; McCarthy et al., 2017). The location of a polysaccharide can also have a significant impact on its purification strategies and cost. For instance, the different methods used for recovery of EPS from the culture broth depend on the characteristics of the microorganisms, the EPS type, and desired purity. A simple drying of culture broth yields a crude product. In contrast, the recovery of high purity EPS requires extensive downstream processing that involves different steps, such as the removal of cells by centrifugation or filtration followed by recovery of polysaccharide from the cell-free supernatant, usually through precipitation. The contaminants are removed through additional purification procedures such as through re-precipitation, deproteinization (chemically or enzymatically), and membrane processes (Sugumaran and V, 2017). The favourable characteristics conferred by bacterial polysaccharides has led to several them becoming routine bioink components. The following sections describe various bacterial polysaccharides routinely used in bioprinting (Table 2).

\subsection{Alginate}


Alginates are one of the leading polymers used in bioprinting. These are unbranched polysaccharides produced by several algal genera such as Laminaria, Macrocystis, Ascophyllum, Ecklonia, Lessonia, and Durvillaea, and bacteria belonging to the Azotobacter and Pseudomonas genera (Lee and Mooney, 2012). In Azotobacter, alginate plays a key role in the formation of desiccation resistant cysts by being the principal component of the capsule-like layer that surrounds these cysts (López-Pliego et al., 2018). In Pseudomonas species, alginate is known to be a component of the extracellular matrix (ECM) that surrounds the bacteria in a biofilm. This is particularly relevant in the opportunistic pathogen, Pseudomonas aeruginosa, where alginate production has been shown to be a key pathogenicity determinant particularly in the infection of the lungs of cystic fibrosis patients (McCarthy et al., 2014; Ramsey and Wozniak, 2005). The structure of alginate consists of two uronic acid residues, including $\beta$ - $D$-mannuronic acid (M) and its C5 epimer $\alpha$ - $L$-guluronic acid (G), linked via 1,4 -glycosidic bonds. The combination and length of these $\mathrm{M}$ and $\mathrm{G}$ residues vary considerably in nature and can significantly impact the physiochemical properties of alginate, with more $\mathrm{G}$ residues are associated with a more rigid polymer (Moradali et al, 2018). Algal-derived alginates have traditionally been used in the biomedical and pharmaceutical sectors for a variety of different purposes including acting as thickeners and stabilizers. This is largely due to the low toxicity and immunogenicity and highlevel tractability. These features have put alginates at the forefront of various applications including drug delivery, cell encapsulation, stem cell culture, and tissue engineering scaffolds. Calcium alginate microspheres have been developed as controlled delivery and release systems (Dounighi et al., 2017; Maestrelli et al., 2017; Remminghorst and Rehm, 2006). For example, islets have been encapsulated in poly-L-ornithine (PLO)-coated alginate microbeads (Khanna et al., 2012), methacrylated glycol chitosan-coated alginate capsules (Hillberg et al., 2015), and in a 
scalable and conveniently retractable device TRAFFIC (thread reinforced alginate fibre for islets encapsulation) (An et al., 2017). The majority of the bioprinting strategies using alginates thus far use algal-derived alginates which are printable at $2-4 \%(\mathrm{w} / \mathrm{v})$ and are structurally-stable and solidify rapidly upon contact with a calcium-based crosslinker $\left(\mathrm{CaCl}_{2}, \mathrm{CaSO}_{4}\right)$ and maintain their 3D shape (Aljohani et al., 2018a; Zhang et al., 2019). These structures have been used to generate a range of synthetic tissue constructs comprised of amniotic fluid-derived stem cells, smooth muscle cells, and biliary epithelial cells (Freeman and Kelly, 2017; Hospodiuk et al., 2017; Xu et al., 2013). The engineering of alginate to improve its capacity for utilization in bioprinting is an area of significant research focus (Jia et al., 2014).

Algal alginates encounter several limitations hindering their use in bioinks, such as a lack of homogeneity in $\mathrm{G} / \mathrm{M}$ residues and fluctuations in molecular weight in accordance with variable environmental conditions (Peteiro, 2018). These have downstream consequences on the capacity of algal-derived alginates to fulfil the specific needs necessary for their further successful uptake by the biomedical sector. Some of these limitations can be overcome by using bacterial-derived alginates, particularly if high-value applications are identified, that can help mitigate the increased cost associated with the bacterial alginate production. The basic viscoelastic properties of bacterial alginates differ from those of algal origin, with bacterial alginates displaying more capacity for modification such as $O$-acetylation, a higher level of monodispersity, and a higher molecular mass (Donati and Paoletti, 2009). The genetic tractability and functional characterization of the alginate biosynthetic pathways in both Azotobacter and Pseudomonas offer much greater capacity to refine and maximize the amounts of native alginates produced by each. These biosynthetic pathways are largely uncharacterized in algae (Moradali et al., 2018). Both bacterial genera also encode a wide variety of enzymes that 
can modify the native alginates such as acetylases that can be used to alter the degree of $O$ acetylation and hence viscosity. These represent tools that can be harnessed to tailor bacterial alginates to specific biomedical needs in a fashion that is not feasible with algal alginates. A greater understanding of the genetic regulatory mechanisms that control the alginate biosynthetic pathways in these bacteria means that they can also be modified to maximize production (Hay et al., 2013).

Alginate has become a popular component of inks used for bioprinting due to its relative inertness, and while a lack of bioactivity is advantageous, it does count against alginate when compared to other bacterial polysaccharides that display dual functionality. It does not support cell adhesion due to its highly hydrate anionic surface and lack of cell binding receptors (Glicklis et al., 2000). To promote cell adhesion for cell culturing and tissue engineering applications, both alginate and alginate-based materials are usually chemically modified by introducing cell adhesive peptides such as Arg-Gly-Asp (RGD) (Llacua et al., 2018), Asp-Gly-Glu-Ala (DGEA) (Alsberg et al., 2001), and Tyr-Ile-Gly-Ser-Arg (YIGSR) (Dhoot et al., 2004), as side chains. RGD is extensively used model adhesion ligand that has complementary integrin receptors (e.g., $\alpha v \beta 3, \alpha 5 \beta 1$ ) on various cell types (Koo et al., 2002; Llacua et al., 2018). It is chemically coupled to the alginate backbone using water-soluble carbodiimide chemistry (Lee et al., 2008). Alginate modification with YIGSR peptides via carbodiimide promoted the adhesion of neural cells (Dhoot et al., 2004). These modified alginate-based materials are widely used in 2D and 3D cell culture and as scaffolds in tissue engineering applications. The relative inertness and non-toxicity of alginate have been extensively evaluated in vitro and in vivo, it might still be immunogenic. For instance, alginates with high $\mathrm{M}$ content are immunogenic and approximately 10 times more potent to induce cytokine production as compared to the alginates with high $\mathrm{G}$ content (Otterlei 
et al., 1991); however, a study has also reported no immunogenic response by alginate implants (Zimmermann et al., 1992). The immunogenicity of alginates could be due to the impurities present in it, in the form of heavy metals, endotoxins, proteins, and polyphenolic compounds, when obtained from different natural sources (Lee and Mooney, 2012), as studies have reported no immunogenic response in animals to a highly purified alginate obtained through a multi-step extraction procedure (Lee and Lee, 2009). Further, alginate-based inks can be impregnated with compounds that confer bioactivity and functionality. Indeed, several examples have been described where alginate-based inks or microbeads have been loaded with antimicrobials and shown to target Helicobacter pylori infection in the stomach (Adebisi et al,, 2015; Gattani et al., 2010). This narrow spectrum delivery window has been shown to successfully prevent the pathogen colonization (Alboofetileh et al, 2014; Hay et al., 2013; Osmokrovic et al., 2018; Russo et al., 2008). The functionality of alginate as ink for bioprinting is continuously developing with different crosslinking agents or polymer combinations being identified to tailor the properties of these inks to a given purpose (Madzovska-Malagurski et al., 2016). The capacity for alginate-based inks to be used as a vector for the targeted delivery of antimicrobials or to act as antibiofilm coatings is rapidly developing and these inks may represent a key tool in the efforts to prevent and treat antibiotic-resistant infections.

\subsection{Bacterial cellulose}

Another common bacterial polymer used in bioprinting is bacterial cellulose (BC). BC is a natural polymer produced by several bacterial genera, such as Acetobacter, Agrobacterium, Achromobacter, Aerobacter, Azotobacter, Sarcina ventriculi, Salmonella, Escherichia, and Rhizobium (Jung et al., 2007; Ullah et al., 2017) and Glucanacetobacter hansenii-based cell-free systems (Khan et al, 2015; Ullah et al, 2016b). It is produced within the microbial cells in the 
form of $\beta$-1,4-glucan chains which are excreted across the terminal complexes (TCs), present at the outer membrane of bacterial cells, into the culture medium where these crystallize and form high-order structures such as protofibrils, ribbons, and bundles and ultimately form of a hydrogel at the air-medium interface (Endler et al., 2010; Kim et al., 2019) (Fig. 2).

In bacteria, $\mathrm{BC}$ plays different functional roles, such as facilitating plant attachment and flocculation. Compared to plant cellulose, which is one of the most abundant polymers on earth, BC has several distinct advantages; including high purity, hydrophilicity, and a finer 3D fibrous structure (Ul-Islam et al., 2019a). Furthermore, it demonstrates a high tensile strength, shearthinning capacity, flexibility, and chemical stability (Gao et al., 2017, 2016). It is highly porous, non-toxic, and biocompatible allowing not only the attachment and proliferation of different mammalian cells such as pluripotent stem cells (de Oliveira, 2012; Dourado et al., 2017) and human keratinocytes (HaCaT) (Khan et al, 2018a) but also allows the infiltration of cells (osteoblasts MC3T3-E1) into its 3D matrix (Khan et al., 2018b). This has led to BC being explored in a diverse array of biomedical applications; the greatest success has been seen in its use in wound dressings with several commercial BC-based wound dressings available (BioFill ${ }^{\mathrm{TM}}$, XCell) and sustained drug delivery applications (Li et al., 2018). Its capacity to form a protective layer over a wound is due to the small pores in the nano-fibrillar network, which prevent bacteria from entering a wound and promote healing (Czaja et al., 2007; Fontana et al., 1990; Sulaeva et al, 2015). Being a hydrogel, BC resembles the natural ECM. Its 3D nanofibrous network structure and morphological similarities with collagen (Lamboni et al., 2019; Lee et al., 2015), make it an attractive material for cell immobilization, cell support, and natural ECM scaffolds (El-Hoseny et al., 2015). Natural ECM contains several signals that are received by cell surface receptors and contribute to cell adhesion and fate by influencing cellular 
activities such as proliferation, migration, and differentiation. As pristine $\mathrm{BC}$ provides a less adhesive surface to the growth of cells due to the absence of adhesive ligands seen in natural ECM, the immobilization of different ECMs (e.g., collagen, elastin, hyaluronan), growth factors such as basic fibroblast, human epidermal growth factor, and keratinocyte growth factor (Fu et al., 2013), RGD (Llacua et al., 2018), and its compositing with other biocompatible polymers such as gelatin (Khan et al., 2018a) and chitosan (Ul-Islam et al., 2019b), significantly improve its biocompatibility to support the adhesion, proliferation, and migration of cells within its interconnected porous structure (Halib et al., 2019; Martínez Ávila et al., 2016). However, beyond creating a physical barrier, pristine $\mathrm{BC}$ lacks innate antibacterial and antifungal properties; this has led to the development of enhancement strategies whereby it is impregnated with different antimicrobials or nanoparticles such as silver (Maneerung et al., 2008), gold (Khan et al, 2018b), zinc oxide (Ul-Islam et al., 2014), and titanium dioxide (Ullah et al., 2016a), as well as cationic peptides (Fürsatz et al., 2018) to improve the anti-infective capacity of BC-based wound dressings (Di et al., 2017; Ul-Islam et al., 2011). In bioprinting, the application of cellulose has been dominated by the generation of ductile films or mats produced through electrospinning, a technique used to produce one-dimensional (1D) fibrous materials (Maria Manzine Costa et al., 2012). The direct use of BC in bioprinting has been limited by its poor solubility in common solvents owing to the presence of regular intra- and inter-molecular hydrogen bonding that stabilizes its reticulate structure. Nevertheless, it is used as a component of bioinks, for example with alginate, where the excellent shear thinning properties of $\mathrm{BC}$ are combined with the rapid crosslinking activity of alginate, to print anatomically accurate cartilage structures loaded with human chondrocytes using electromagnetic jet printing technology (Markstedt et al., 2015). One of the most recent methods involves the incorporation of BC 
producing strains such as A. xylinum into the already established hydrogel-based inks. These inks are then printed over a given surface in a defined geometry and incubated for a defined period. The ink constituents can then be washed out, leaving only a network of nanofibrillated BC (Schaffner et al., 2017).

\subsection{Hyaluronic acid}

Hyaluronic acid (HA) is a linear polysaccharide composed of $\beta-(1 \rightarrow 4)$ linked $D$ glucuronic acid and $N$-acetyl- $\beta$ - $(1 \rightarrow 3)$ linked $D$-glucosamine. It is commonly found in the ECM of vertebrate epithelial, neural, and connective tissues. HA possesses a wide range of features that make it amenable to bioprinting, such as high viscoelasticity, degradability, and low immunogenicity (Aljohani et al., 2018b). Owing to these features, it has been used in biomedical applications since the 1950s. It is; however, also produced by different bacteria including Streptococci spp., Pasteurella multocida, and Cryptococcus neoformans where it is believed to play a role in immune evasion, encapsulating the cells to allow them to escape detection from the host's immune system (Sze et al., 2016). Due to the high levels of proteinaceous contamination, time, and cost associated with the extraction of HA from eukaryotic tissues, biotechnological production methods using bacterial or cell-free systems is the preferred method of production. Synthetic biology approaches have been used to express the Streptococci HA biosynthetic cluster in industrial bacterial strains such as Bacillus subtilis. This organism is capable of being grown in fermenters allowing large-scale production of HA (Widner et al., 2005). Currently, HA is widely used in a variety of biomedical applications such as wound healing, surface coatings, and sustained/targeted release formulations (Moscovici, 2015). Its physical properties and prior use in biomedical applications have led to HA becoming one of the most popular polymers used in bioprinting. It is typically blended with dextran to overcome stability issues that derive from its 
high hydrophilicity (Aljohani et al., 2018b; Pescosolido et al., 2011a). Numerous examples have demonstrated how bioprinted scaffolds based on HA can be used to mimic the native ECM, allowing cellular adhesion, growth, and proliferation (Bian et al, 2016a; Ning et al., 2018). Like many of the bioink polymers in general use, HA does not possess any intrinsic antimicrobial properties other than its capacity to impede the passage of bacteria in the pericellular space of eukaryotic tissues. However, it has been doped with gold, silver, copper, and palladium nanoparticles as well as with antimicrobials to prevent bacterial attachment and the colonization of tissue scaffolds (Cárdenas-Triviño et al., 2017; Matsuno et al., 2006). As more HA crosslinking variants are discovered and explored, the capacity to have more control over features such as the gelation process and subsequent degradation kinetics facilitating greater functionality and the eventual development of smart bioinks (Bian et al., 2016a, Bian et al., 2016b). Various strategies to improve the functionality of HA based bioinks have been developed these include the introduction of hydrophobic moieties and crosslinking with various chemical functional groups such as with photo cross-linkable dextran derivatives, hydroxyethyl methacrylate derivatized dextran (Pescosolido et al., 2011b), thiolation and gelatin-modification (Skardal et al., 2010), functionalization of thiolated HA and gelatin (Aleksander Skardal et al., 2010), grafting of poly(lactic-co-glycolic acid) with incorporated bone morphogenesis protein-2 (BMP-2) (Park et al., 2011). 
Table 2. Application of different bacterial polysaccharides in 3D printing

\begin{tabular}{|c|c|c|c|c|c|c|}
\hline \multirow{2}{*}{$\begin{array}{c}\text { Bacterial } \\
\text { polys accharides }\end{array}$} & Crosslinker/ & Printing & & \multirow{2}{*}{\multicolumn{2}{|c|}{ Functions }} & \\
\hline & $\begin{array}{l}\text { reinforced } \\
\text { material }\end{array}$ & method & Improved features & & & Ref. \\
\hline \multirow[b]{2}{*}{ Alginate } & \multirow[b]{2}{*}{ Calcium sulfate } & \multirow[b]{2}{*}{ Extrusion } & & \multirow[b]{2}{*}{$\begin{array}{c}\text { Mesenchymal } \\
\text { stem cells }\end{array}$} & Controlled & \\
\hline & & & $\begin{array}{l}\text { Improved mechanical } \\
\text { properties (Young's } \\
\text { moduhus, degradation } \\
\text { rate) }\end{array}$ & & $\begin{array}{l}\text { growth factor } \\
\text { delivery for } \\
\text { differentiation of } \\
\text { stem cells }\end{array}$ & $\begin{array}{l}\text { (Freeman } \\
\text { and Kelly, } \\
\text { 2017) }\end{array}$ \\
\hline & & & Shape and size stability, & & & \\
\hline $\begin{array}{l}\text { Bacterial } \\
\text { cellulose }\end{array}$ & Alginate & $\begin{array}{l}\text { Stereolith } \\
\text { ography }\end{array}$ & $\begin{array}{l}\text { cell-laden, patient-specific } \\
\text { auricular constructs, high } \\
\text { cell density, and }\end{array}$ & $\begin{array}{l}\text { Human nasal } \\
\text { chondrocytes }\end{array}$ & $\begin{array}{l}\text { Patient-specific } \\
\text { auricular cartilage } \\
\text { tissue engineering }\end{array}$ & $\begin{array}{c}\text { (Markstedt et } \\
\text { al, 2015) }\end{array}$ \\
\hline
\end{tabular}




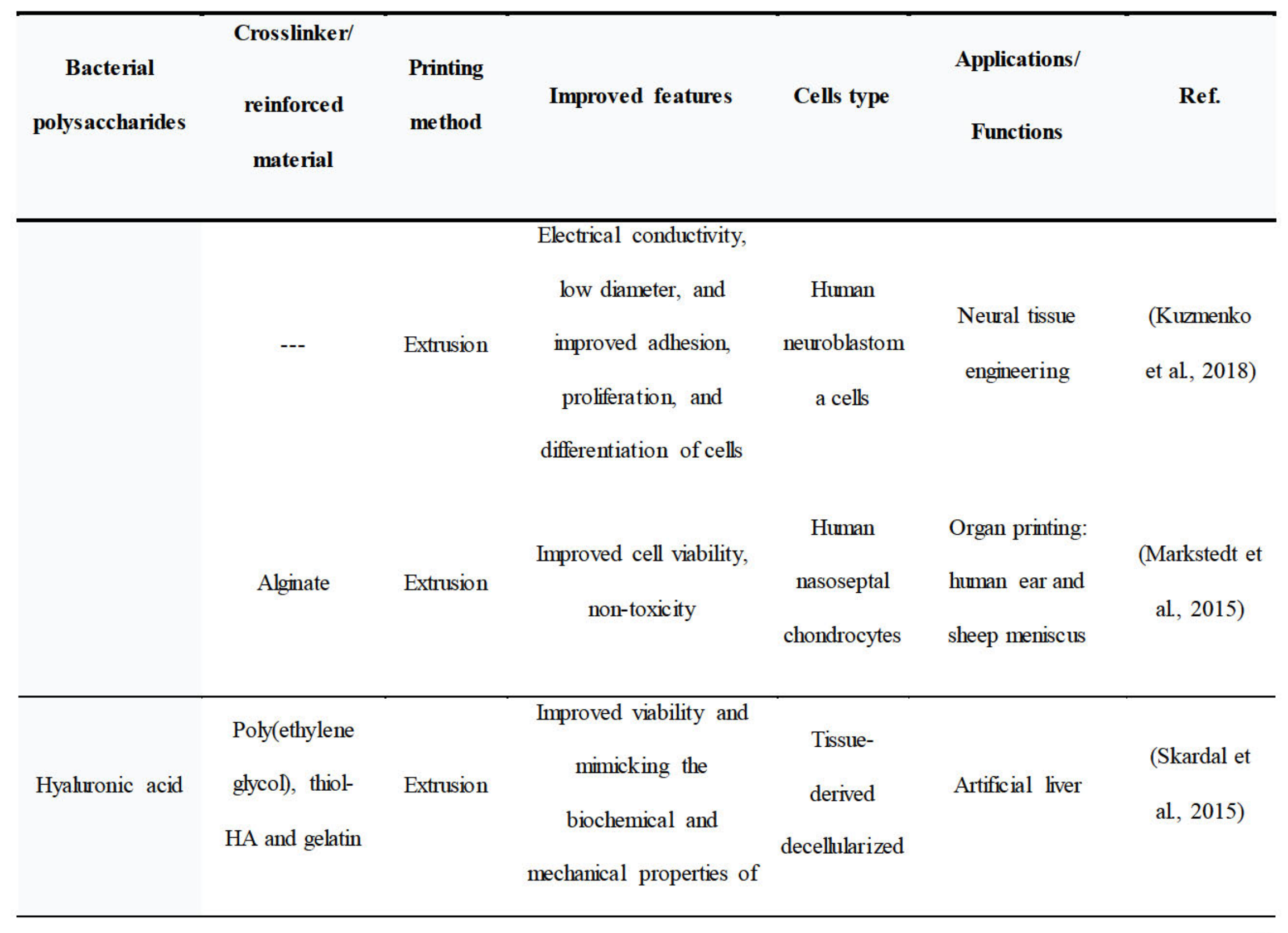




\begin{tabular}{|c|c|c|c|c|c|c|}
\hline \multirow{3}{*}{$\begin{array}{l}\text { Bacterial } \\
\text { polysaccharides }\end{array}$} & Crosslinker/ & Printino & & & Applications/ & \\
\hline & $\begin{array}{l}\text { reinforced } \\
\text { material }\end{array}$ & & Improved features & Cells type & Functions & Ref. \\
\hline & & & native tissue & $\mathrm{ECM}$ & & \\
\hline Gellan & $\begin{array}{l}\text { Calcium } \\
\text { chloride and } \\
\text { Dulbecco's } \\
\text { Modified } \\
\text { Eagle Medium } \\
\text { (DMEM) }\end{array}$ & $\begin{array}{l}\text { Hand-held } \\
\text { printing } \\
\text { (manual) }\end{array}$ & $\begin{array}{c}\text { Peptide-modification, } \\
\text { improved cell } \\
\text { proliferation, and ECM } \\
\text { formation }\end{array}$ & $\begin{array}{l}\text { Primary } \\
\text { cortical } \\
\text { neurons }\end{array}$ & $\begin{array}{l}\text { Formation of } \\
\text { complex and layered } \\
\text { structures such as } \\
\text { brain-like, cell } \\
\text { behavior studies, } \\
\text { and treatment of } \\
\text { neural disorders }\end{array}$ & $\begin{array}{l}\text { (Lozano et } \\
\text { al, 2015) }\end{array}$ \\
\hline Dextran & Gelatin & Extrusion & $\begin{array}{l}\text { Tunable gelation time and } \\
\text { phase separation, simple } \\
\text { and spontaneous fixation, }\end{array}$ & $\begin{array}{l}\text { Human } \\
\text { dermal } \\
\text { fibroblasts }\end{array}$ & --- & $\begin{array}{l}\text { (Du et al. } \\
\text { 2017) }\end{array}$ \\
\hline
\end{tabular}




\begin{tabular}{|c|c|c|c|c|c|c|}
\hline \multirow{4}{*}{$\begin{array}{c}\text { Bacterial } \\
\text { polys accharides }\end{array}$} & Crosslinker/ & \multirow{4}{*}{$\begin{array}{l}\text { Printing } \\
\text { method }\end{array}$} & \multirow[b]{3}{*}{ Improved features } & \multirow{2}{*}{\multicolumn{3}{|c|}{ Applications/ }} \\
\hline & \multirow{3}{*}{$\begin{array}{l}\text { reinforced } \\
\text { material }\end{array}$} & & & & & \\
\hline & & & & Cells type & \multirow{2}{*}{ Functions } & Ref. \\
\hline & & & thermal stability & (HDFs) & & \\
\hline \multirow{8}{*}{ Xanthan } & & & Improved viscosity, & & \multirow{3}{*}{$\begin{array}{c}\text { Nutritious food } \\
\text { systems }\end{array}$} & \multirow{3}{*}{$\begin{array}{c}\text { (Z. Liu et al, } \\
\text { 2018) }\end{array}$} \\
\hline & Mashed potato & Extrusion & storage moduhus $\left(\mathrm{G}^{\prime}\right)$, and & --- & & \\
\hline & & & loss moduhus $\left(\mathrm{G}^{\prime \prime}\right)$ & & & \\
\hline & & & & \multirow{4}{*}{---} & \multirow{2}{*}{$\begin{array}{c}\text { Fortified 3D printed } \\
\text { foods with }\end{array}$} & \multirow{5}{*}{$\begin{array}{c}\text { (Azam et al, } \\
\text { 2018) }\end{array}$} \\
\hline & Vitamin D and & & & & & \\
\hline & & & & & diversified physical & \\
\hline & blends & & loss moduhus $\left(\mathrm{G}^{\prime \prime}\right)$ & & & \\
\hline & & & & & properties & \\
\hline
\end{tabular}




\subsection{Gellan}

Gellan gum is an anionic extracellular polysaccharide produced by the bacteria Sphingomonas elodea. It is composed of repeating units consisting of $\alpha$ - $L$-rhamnose, $\beta-D$ glucose, and $\beta$ - $D$-glucoronate. It has been used in a wide variety of applications in the food industry, including as a gelling/stabilizing agent. In the biomedical industry, it has been used in ophthalmic treatments and sustained drug release formulations (Ferris et al., 2013; Posadowska et al., 2016; Yu et al., 2017). It has also been explored in wound dressings; however, it has not enjoyed the success of other bacterial polymers such as BC due to its soft texture and low thermal stability. These issues are for the most part being overcome with the advent of 3D printing technology. Gellan gum has a number of properties that make it amenable to use in inks for bioprinting, including its capacity to be crosslinked by cation concentrations in the low millimolar range, high monodispersity, low immunogenicity, excellent rheological properties, and a high gelling efficiency at $37^{\circ} \mathrm{C}$ (Ferris et al., 2013; Silva-Correia et al., 2011; Smith et al., 2007). These properties have allowed gellan gum to be used successfully to create scaffolds for bone, fibroblasts, and neural cultures (Lozano et al., 2015; Silva-Correia et al., 2011). One significant disadvantage hampering the further development of gellan gum-based inks, however, is that significant degradation of structural integrity has been observed over time in vivo. This is being overcome by the utilization of different crosslinking approaches such as UV photocrosslinking; however, this requires chemical modification of the polymer to add methyacrylates, but this has not been shown to impact the cytotoxicity of gellan (Silva-Correia et al., 2011). It has also been shown that the degradation properties of gellan gum in the synthetic body fluid can be altered by changing the ratio of surface area per mass, demonstrating that this must be careful consideration when designing scaffolds for in vivo use (Yu et al., 2017). Gellan has also been 
assessed as part of a polymer blend with alginate where it was shown to improve several features such as shape fidelity, mechanical strength, and cell attachment as opposed to a pure alginate gel (Akkineni et al., 2016). A study reported that the addition of glycerol significantly improved the mechanical properties by overcoming the brittleness caused by the rigid interconnection among the polymeric chains, it also improved the muco-adhesion capacity (Paolicelli et al., 2018). Further, the addition of $\mathrm{TiO}_{2}$ nanoparticles not only improved the mechanical strength and swelling, but the small shielding effect of $\mathrm{TiO}_{2}$ prevented the degradation and retained the stability of gellan- $\mathrm{TiO}_{2}$ film. Further, the gellan- $\mathrm{TiO}_{2}$ film generated reactive oxygen species (e.g., $\mathrm{H}_{2} \mathrm{O}_{2}, \mathrm{OH}^{*}$, and $\left.\mathrm{O}_{2}^{-}\right)$at low wavelength $(\leq 400 \mathrm{~nm})$ which possess antibacterial activity (Ismail et al., 2019; Ullah et al., 2016a). Similarly, formulations have been blended that contain compounds with antibacterial activity such as zinc- and strontium-loaded glass microparticles (Douglas et al., 2018). This remains an area for potential exploration to improve the transition of 3D printed structures using gellan into the clinic.

\subsection{Dextran}

Dextran is a neutral polymer with $\alpha-(1 \rightarrow 6)$ and $\alpha-(1 \rightarrow 4)$ glucopyranosyl linkages produced by several lactic acid-producing bacteria including Leuconostoc mesenteroides and Streptococcus mutans. It was initially discovered by Louis Pasteur as a fermentation by-product of wine and went on to become one of the first microbial polysaccharides to be used in a clinical setting when it was approved for use as a plasma volume expander in the 1950s (Moscovici, 2015; Pasteur, 1861). It has been used as a key component of hydrogels in burn wound dressings, where it has been shown to promote rapid functional neovascularization and wound healing processes (Sun et al., 2011). Its use in bioprinting; however, has been relatively limited and largely confined to being used as a component of polymer blends. An oxidized form of dextran 
has also been used in combination with gelatin to create ink for bioprinting with a tuneable gelation time based on the thermal sensitivity of gelatin and subsequent Schiff-base crosslinking of oxidized dextran (Du et al., 2017). Dextran modified with hydroxyethyl methacrylate (to be made photosensitive), has been used as a blend with HA to overcome its stability issues associated with its high hydrophilicity. By varying the concentration of modified dextran in ink, it was possible to alter key features such as the mechanical properties and degradation time (Pescosolido et al., 2011a). Dextran does not possess any antibacterial activity but has been modified through the addition of aldehyde groups or by blending with bioactive compounds to exhibit antibacterial and anti-biofilm activity, highlighting its potential as a component of antimicrobial inks for bioprinting (Aziz et al., 2012; De Cicco et al., 2014).

\subsection{Xanthan}

Xanthan is an exopolysaccharide (EPS) produced by the plant pathogen Xanthomonas campestris through the aerobic fermentation of glucose or sucrose. It is a heteropolysaccharide composed of glucose, mannose, glucuronic acid, acetate, and pyruvate. It has been used as a food additive for almost 50 years due to its ability to function as a thickener. Due to its long term use as a food additive and biological inertness, much of the focus of the applications of xanthan gum to $3 \mathrm{D}$ printing technology has focused on $3 \mathrm{D}$ food printing, where its shear-thinning capacity and viscosity at low concentrations are properties that allow it to act as a rheological modifier, improving the 3D printing properties of a given food (Azam et al., 2018; Z. Liu et al., 2018). These properties have also led it to be a component of some hydrogels used for tissue regeneration studies (Elizalde-Peña et al, 2017). Like many of biologically inert bacterial polysaccharides, its functionality has been improved by the incorporation of antifungals and 
antibacterial elements allowing the targeted treatment of infections using hydrogel formulations (Silva Santos et al., 2016; Singh et al., 2019).

\subsection{Bioactive bacterial polysaccharides}

Bacteria are known to produce a diverse range of polysaccharides. The primary use of bacterial polysaccharides in bioprinting is to confer structural properties. However, many have been shown to also have additional bioactivities. Recently the number of bacteria identified that are capable of producing polysaccharides with antibiofilm activity has risen sharply, suggesting this is an under-identified strategy employed by bacteria to secure a favourable environment from the competing species (Table 3) (Bernal and Llamas, 2012; Junter et al., 2016; Rendueles et al., 2013). These polysaccharides typically have broad-spectrum activity against both Grampositive and Gram-negative pathogens without impacting their growth (Abu Sayem et al., 2014; Bendaoud et al., 2011; He et al., 2010; Jiang et al., 2011; Kanmani et al., 2011; Karwacki et al., 2013; Li et al., 2014; Spanò et al., 2016; Valle et al., 2006; J. Wang et al., 2015). This suggests that the capacity to develop resistance to these antibiofilm polysaccharides is low as compared to traditional antibiotic therapies (Travier et al., 2013).

Several different potential mechanisms of action for these anti-biofilm polysaccharides have been proposed, including biomasking, the disruption of gene expression, the alteration of biotic/abiotic surface properties and the activation of biofilm degrading agents (Junter et al, 2016; Rendueles et al., 2013). r-EPS obtained from Lactobacillus acidophilus A4 has been shown to inhibit biofilm formation by downregulating the expression of genes required for chemotaxis and curli formation in enterohemorrhagic Escherichia coli (Kim et al., 2009). Significantly, a number of these polysaccharides have been shown to be capable of dispersing the already established biofilms (Jiang et al, 2011; Wu et al., 2016), suggesting the biomedical 
implication for such a polysaccharide may not be just prophylactic. Some of these antibiofilm polysaccharides have also been shown to exhibit further biologically relevant activities such as antioxidant activity and metal ion chelation activity as well as possessing features amenable to incorporation into bioinks such as high levels of thermostability, a pseudoplastic rheology, emulsifying activity, and water solubility (Abid et al., 2018; Li et al., 2014, 2015; Sardar et al., 2015; Spanò et al., 2016; Wu et al., 2016).

In comparison to antibiofilm polysaccharides, only a small number of bacteria-derived polysaccharides have been identified that display antibacterial activity (He et al., 2010; J. Liu et al., 2018). Of these, HS-P03, a polysaccharide composed of glucose, mannose, and galactose derived from Streptomyces virginia $\mathrm{H} 03$ has been shown to be active against both Gram-negative and Gram-positive bacteria. The precise mechanism of action for this polysaccharide is yet to be determined, although it is proposed to disrupt the cytoplasmic membrane and cell wall leading to cell death (He et al, 2010). The capacity for these polysaccharides to be functionally integrated into ink for bioprinting as either bioactive constituents or core conveyors of form is dependent on further investigation of their biophysical properties. This collection of bioactive bacterial polysaccharides is consistently expanding particularly as the likelihood of finding functionally active and biologically relevant polysaccharides is higher among bacteria due to the close proximity that exists in microbial communities and the evolution of antimicrobial and antibiofilm polysaccharides that may offer competitive advantages within these environmental niches. The amenability of many of these polysaccharides to being utilized as a bioink is yet to be determined, but many have the potential to form the starting blocks for bioactive inks. 
Table 3. Antibiofilm and antibacterial polysaccharides

\begin{tabular}{|c|c|c|c|c|c|}
\hline Name & Source & $\begin{array}{l}\text { Main } \\
\text { components }\end{array}$ & Bioactivity & Additional features & Ref. \\
\hline EPS1-T14 & Bacillus licheniformis T14 & Fructose, Fucose & Antibiofilm & $\begin{array}{c}\text { Soluble in water, non- } \\
\text { cytotoxic }\end{array}$ & $\begin{array}{c}\text { (Spanò et al., } \\
\text { 2016) }\end{array}$ \\
\hline LPS & Marinobacter litoralis & $\begin{array}{c}\text { Fucose, Xylose, } \\
\text { Mannose }\end{array}$ & Antibiofilm & Membrane-bound, non-toxic & $\begin{array}{c}\text { (Sardar et al, } \\
\text { 2015) }\end{array}$ \\
\hline dLPS & Vibrio vulnificus & $\begin{array}{l}\text { Glucosamine, } \\
\text { galactosamine }\end{array}$ & Antibiofilm & $\begin{array}{l}\text { Activity-dependent on } \mathrm{O} \text { - } \\
\text { antigen, Gram-negative only }\end{array}$ & (Lee et al, 2016) \\
\hline TB-PS & $\begin{array}{c}\text { Psuedoalteromonas ulvae } \\
\text { strain TC16 }\end{array}$ & Ghucose & Antibio film & --- & $\begin{array}{c}\text { (Brian-Jaisson et } \\
\text { al, 2016) }\end{array}$ \\
\hline B4-EPS & Arthrobacter sp. B4 & Galactose & Antibiofilm & $\begin{array}{l}\text { Impacts Gram-negatives and } \\
\text { Gram-positives. Optimized for } \\
\text { low-cost and large-scale } \\
\text { production }\end{array}$ & (Li et al, 2014) \\
\hline r-EPS & Lactobacillus acidophilus A4 & Unknown & Antibiofilm & Impacts both Gram-negatives & (Kim et al, \\
\hline
\end{tabular}




\begin{tabular}{|c|c|c|c|c|c|}
\hline EPS-SP1 & Bacillus licheniformis SP1 & $\begin{array}{l}\text { Glycerol, } \\
\text { Galactose }\end{array}$ & Antibiofilm & $\begin{array}{l}\text { Impacts both Gram-negatives } \\
\text { and Gram-positives }\end{array}$ & $\begin{array}{l}\text { (Abu Sayem et } \\
\text { al, 2014) }\end{array}$ \\
\hline Ps1 & Pseudomonas aeruginosa & $\begin{array}{l}\text { Ghicose, } \\
\text { Mannose, } \\
\text { Rhamnose }\end{array}$ & Antibio film & $\begin{array}{l}\text { Only demonstrated for Gram- } \\
\text { positives }\end{array}$ & (Qin et al, 2009) \\
\hline Pe1 & Pseudomonas aeruginosa & $\begin{array}{l}\text { Galactosamine, } \\
\text { Glucosamine }\end{array}$ & Antibiofilm & $\begin{array}{l}\text { Only demonstrated for Gram- } \\
\text { positives }\end{array}$ & (Qin et al, 2009) \\
\hline EPS-BK6 & $\begin{array}{c}\text { Oceonobacillus iheyensis } \\
\text { BK6 }\end{array}$ & $\begin{array}{l}\text { Mannose, Ghicose } \\
\text { Arabinose }\end{array}$ & Antibiofilm & $\begin{array}{l}\text { Demonstrates thermostability, } \\
\text { pseudoplastic rheology, and } \\
\text { emulsifying activity. Only } \\
\text { tested for Gram-positives }\end{array}$ & $\begin{array}{l}\text { (Kavita et al., } \\
\text { 2014) }\end{array}$ \\
\hline EPS-BMS & Leuconostoc citreum BMS & $\begin{array}{l}\text { Glucose, } \\
\text { Mannose, } \\
\text { Fructose }\end{array}$ & Antibiofilm & $\begin{array}{l}\text { High thermostability, active } \\
\text { against Gram-positives and } \\
\text { negatives, and disrupts } \\
\text { established biofilms. }\end{array}$ & $\begin{array}{l}\text { (Abid et al. } \\
\text { 2018) }\end{array}$ \\
\hline
\end{tabular}




\begin{tabular}{|c|c|c|c|c|c|}
\hline EPS-TMS & $\begin{array}{c}\text { Leuconostoc mesenteroides } \\
\text { TMS }\end{array}$ & $\begin{array}{l}\text { Ghucose, } \\
\text { Mannose, } \\
\text { Fructose }\end{array}$ & Antibio film & $\begin{array}{l}\text { High thermostability. Active } \\
\text { against Gram-positives and } \\
\text { negatives }\end{array}$ & $\begin{array}{c}\text { (Abid et al, } \\
\text { 2018) }\end{array}$ \\
\hline EPS-DPS & $\begin{array}{c}\text { Pediococcus pentosaceus } \\
\text { DPS }\end{array}$ & $\begin{array}{l}\text { Glucose, } \\
\text { Mannose, } \\
\text { Fructose }\end{array}$ & Antibio film & $\begin{array}{l}\text { High thermostability, active } \\
\text { against Gram-positives and } \\
\text { negatives }\end{array}$ & $\begin{array}{l}\text { (Abid et al., } \\
\text { 2018) }\end{array}$ \\
\hline EPS-CM & $\begin{array}{l}\text { Leuconostoc pseudo- } \\
\text { messenteroides } C M\end{array}$ & $\begin{array}{l}\text { Glucose, } \\
\text { Mannose, } \\
\text { Fructose }\end{array}$ & Antibio film & $\begin{array}{l}\text { High thermostability, active } \\
\text { against Gram-positives and } \\
\text { negatives }\end{array}$ & $\begin{array}{l}\text { (Abid et al. } \\
\text { 2018) }\end{array}$ \\
\hline PI80 EPS & Streptococcus phocae PISO & $\begin{array}{l}\text { Arabinose, } \\
\text { Fructose, } \\
\text { Galactose }\end{array}$ & Antibiofilm & $\begin{array}{l}\text { Active against Gram-positives } \\
\text { and Gram-negatives. } \\
\text { Antioxidant activity }\end{array}$ & $\begin{array}{c}\text { (Kanmani et al, } \\
\text { 2011) }\end{array}$ \\
\hline $\begin{array}{l}\text { EPS- } \\
\text { YW32 }\end{array}$ & $\begin{array}{c}\text { Lactobacillus plantarum } \\
\qquad Y W 32\end{array}$ & $\begin{array}{l}\text { Mannose, } \\
\text { Fructose, } \\
\text { Galactose }\end{array}$ & Antibio film & $\begin{array}{c}\text { Active against Gram-positives } \\
\text { and negatives }\end{array}$ & $\begin{array}{l}\text { (J. Wang et al, } \\
\text { 2015) }\end{array}$ \\
\hline EPS- & Lactobacillus plantarum & Xylose, & Antibiofilm & Active against Gram-positives & (Liu et al, 2017) \\
\hline
\end{tabular}




\begin{tabular}{|c|c|c|c|c|c|}
\hline WLPL04 & WLPLO4 & $\begin{array}{l}\text { Ghucose, } \\
\text { Galactose }\end{array}$ & & and negatives & \\
\hline EPS4 & $\begin{array}{l}\text { Lactobacillus plantarum } \\
\text { EPS4 }\end{array}$ & $\begin{array}{c}\text { Galactose, Ribose, } \\
\text { Fructose }\end{array}$ & Antibiofilm & $\begin{array}{l}\text { Active against Gram-positives } \\
\text { and negatives. Inhibits cell- } \\
\text { surface and cell-cell } \\
\text { interaction }\end{array}$ & $\begin{array}{l}\text { (Pradeepa et al, } \\
\text { 2016) }\end{array}$ \\
\hline $\begin{array}{l}\text { EPS- } \\
\text { MB2-1 }\end{array}$ & $\begin{array}{l}\text { Lactobacillus helveticus } \\
\qquad M B 2-1\end{array}$ & $\begin{array}{l}\text { Galactose, } \\
\text { Ghucose, Mannose }\end{array}$ & Antibio film & $\begin{array}{l}\text { Displays emulsifying, } \\
\text { antioxidant, and metal ion } \\
\text { chelating activities. Active } \\
\text { against Gram-positive and } \\
\text { negatives. }\end{array}$ & (Li et al, 2014) \\
\hline A101 & Vibrio sp. QY101 & $\begin{array}{l}\text { Galacturonic acid, } \\
\text { Ghucuronic acid, } \\
\text { Rhammose and } \\
\text { Ghucosamine }\end{array}$ & Antibio film & $\begin{array}{l}\text { Active against Gram-positives } \\
\text { and negatives }\end{array}$ & $\begin{array}{l}\text { (Jiang et al, } \\
\text { 2011) }\end{array}$ \\
\hline EPS273 & Pseudomonas stutzeri 273 & Ghucosamine, & Antibio film & Exhibits antioxidant potential, & (Wu et al, 2016) \\
\hline
\end{tabular}




\begin{tabular}{|c|c|c|c|c|c|}
\hline & & $\begin{array}{l}\text { Rhamnose, } \\
\text { Glucose, Mannose }\end{array}$ & & $\begin{array}{l}\text { inhibits virulence factor } \\
\text { production in } P \text {. aeruginosa, } \\
\text { tested in Zebrafish, no } \\
\text { cytotoxicity. }\end{array}$ & \\
\hline $\begin{array}{l}\text { PAM } \\
\text { galactan }\end{array}$ & Kingella kingae PYKK081 & Galactose & Antibio film & $\begin{array}{l}\text { Active against Gram-positives, } \\
\text { Gram-negatives, and Candida }\end{array}$ & $\begin{array}{l}\text { (Bendaoud et al, } \\
\text { 2011) }\end{array}$ \\
\hline CPS-IA5 & $\begin{array}{c}\text { Actinobacillus } \\
\text { pleuropneumoniae serotype } \\
5\end{array}$ & Unknown & Antibiofilm & $\begin{array}{l}\text { Capsular, thermostable, and } \\
\text { active against Gram-positives } \\
\text { and negatives. Inhibits cell-to- } \\
\text { cell and cell-to-surface } \\
\text { interactions }\end{array}$ & (Karwacki et al, \\
\hline CPS & Klebsiella pneumoniae & $\begin{array}{l}\text { Galactose, } \\
\text { Ghucose, } \\
\text { Rhamnose, } \\
\text { Ghucuronic acid, } \\
\text { and Ghucosamine }\end{array}$ & Antibiofilm & $\begin{array}{l}\text { Capsular, thermostable, and } \\
\text { active against Gram-positives } \\
\text { and negatives }\end{array}$ & $\begin{array}{c}\text { (Dos Santos } \\
\text { Goncalves et al, } \\
\text { 2014) }\end{array}$ \\
\hline
\end{tabular}




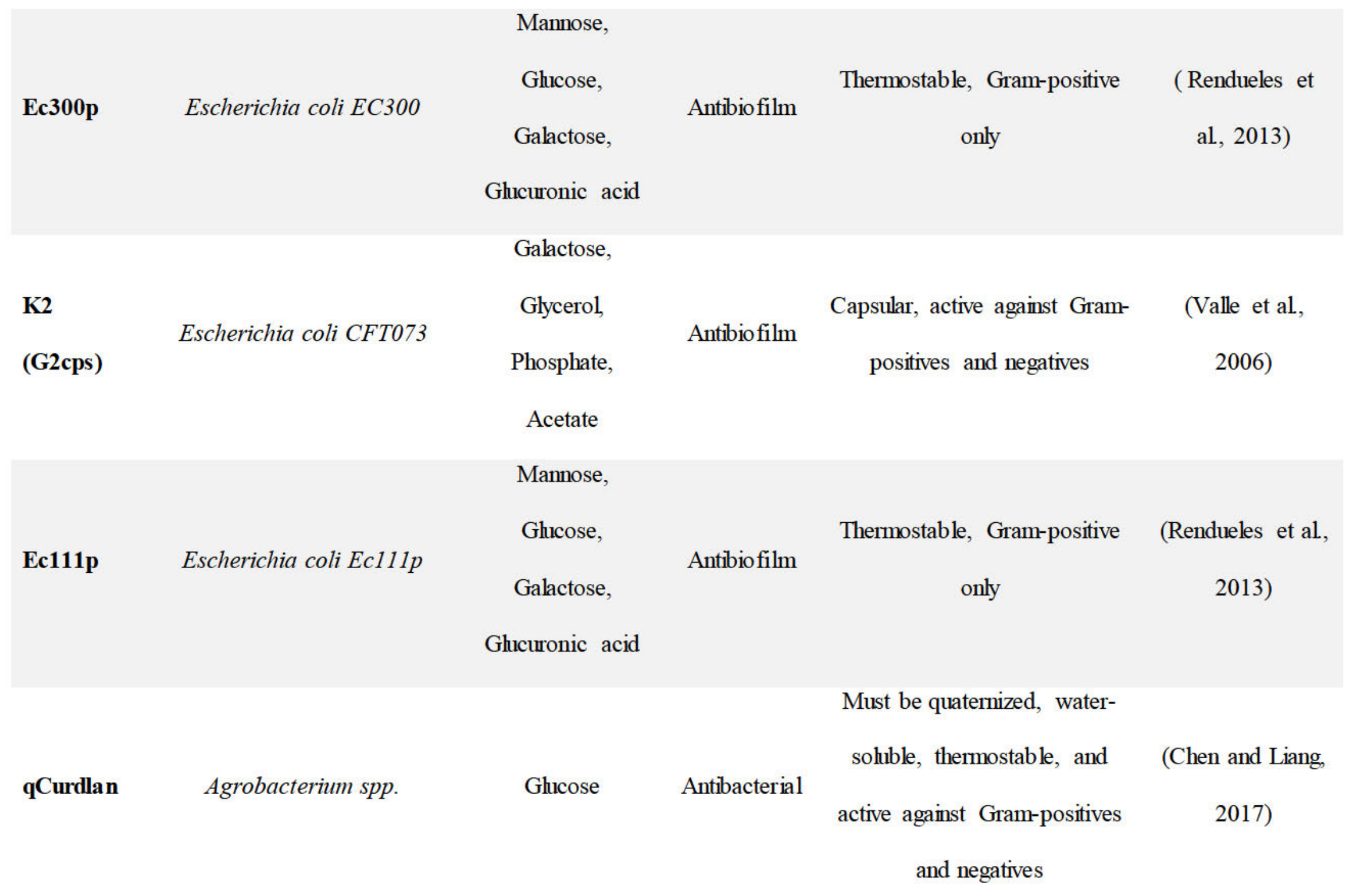




\begin{tabular}{|c|c|c|c|c|c|}
\hline \multirow[b]{2}{*}{ PS-H03 } & \multirow[b]{2}{*}{ Streptomyces virginia $\mathrm{HO} 3$} & Ghucose, & \multicolumn{3}{|c|}{ Thermostable, and active } \\
\hline & & $\begin{array}{l}\text { Mannose, } \\
\text { Galactose }\end{array}$ & Antibacterial & $\begin{array}{c}\text { against Gram-positives and } \\
\text { negatives }\end{array}$ & (He et al, 2010) \\
\hline ECP & $\begin{array}{l}\text { Enterobacter cloacae } \\
\text { CMCC } 45301\end{array}$ & Ghucose & Antibacterial & $\begin{array}{c}\text { Antibacterial activities } \\
\text { mediated through cell } \\
\text { membrane damage. Activity } \\
\text { only tested on drug-resistant } E \text {. } \\
\text { cloacae }\end{array}$ & $\begin{array}{l}\text { (J. Liu et al., } \\
\text { 2018) }\end{array}$ \\
\hline
\end{tabular}




\section{Limitations to emerging methods}

Many of the limitations of current bioprinting procedures are associated with the preparation of bioinks, which usually takes a few days to several weeks and requires complex preparation procedures. For instance, the preparation of multicomponent bioinks includes the development of appropriate materials with desired structural, shear-thinning, and cytocompatible properties (Ashammakhi et al., 2019). Moreover, limited shelf-life and storage difficulties are major challenges, which compromise the efficacy of printing procedures. For example, most hydrogels of heterogeneous and biomimetic structures are degraded relatively fast and lose their structures in two to three weeks. This issue has been addressed to some extent by introducing reinforcing fibres (Narayanan et al., 2016) or particles (Sawkins et al., 2015; Visser et al., 2015). Further, the shelf-life of bioinks is increased through lyophilization and cryomilling and their subsequent reconstitution before use (Yu et al., 2019). However, the reconstitution of bioinks or their components from the lyophilized state compromises their shelf-life and local working time (Hornick and Rajan, 2015; Murphy and Atala, 2014). Further, the introduction of new features into printers to preserve the newly printed regions, designing of advanced parallel printers, and refining the printing process such as through introduction of continuous liquid interface production (CLIP) (Tumbleston et al., 2015) can help resolve the major issues associated with the limited shelf-life of a bioink. Another major challenge in bioink preparation is defining the balance between the different components of bioink (i.e., materials, cells, and biomolecules). The use of materials with specialized properties, such as smart materials with stimuli-response abilities or shape memory, further complicates the preparation of bioinks.

Another key limitation associated with the current bioprinting technology is the requirements of all hydrogels to be in liquid or semi-liquid state for printing. This indicates that 
the viscosity of printable bioink must be controlled according to the requirements of a bioprinter as well as the desired features of the scaffold to be printed. Difficulties can arise when attempting to control the transition from a liquid to a more rigid structure. In general, all bioinks should form quasi-scaffold structures supporting the adhesion and proliferation of cells after printing, which can be achieved by using hydrogel pre-polymer solutions which are photo- or chemical crosslinking polymers (Araujo et al., 2014; Bajaj et al., 2014). A simple printing process requires that the different printed layers remain connected and provide mechanical support to each other during the printing process. However, the introduction of voids in one layer usually results in the collapsing of subsequent layers, thus resulting in a cascade of offset features and deformed geometry of the printed scaffold. The incorporation of sacrificial materials, such as carbohydrate glass (Miller et al., 2012), Pluronic F-127 (Kolesky et al, 2016, 2014), and gelatin microparticles (Hinton et al., 2015) overcome this discrepancy by providing mechanical support to the subsequent layers during the layer-by-layer printing process. This sacrificial material is removed as soon as the desired geometry is attained. This approach has been successfully used in the printing of microelectrochemical system (MEMS) devices (Luiz E Bertassoni et al., 2014); however, this strategy complicates the overall printing process, such as the requirements of using multiple nozzles as well as the post-printing processing of the printed scaffolds. This indicates that the any substance used as sacrificial material should not only provide mechanical support to the printing scaffold but should also be printable under the same experimental conditions as well as non-toxic to the cells.

The limitations associated with the use of bacterial polysaccharides in bioinks are common with the integration of any new polysaccharide into an ink for bioprinting with the aim to improve its existing features such as thermostability, rheology, water solubility, 
biocompatibility, and degradative capacity, or impart additional features. Such properties govern the fabrication and stability of bioprinted complex structures. While microbial polysaccharides are being exploited for additive manufacturing technologies, their uptake is still limited. The limited uptake of bacterial polysaccharides as biomaterials is at least partly due to costly production methods, difficulty in scalability, and the availability of cheaper synthetic or plant/algal alternatives. However, the emergence of antibiotic resistance has led to an increased interest in bacterial polysaccharides as potential biomaterials for use in a range of medical applications (wound dressings, tissue regeneration, and bone repair) (Moscovici, 2015; Rendueles et al., 2013). This has been supported by the exponentially growing field of synthetic biology where the polysaccharide synthesizing gene clusters can be inserted into the synthetic scaffolds or workhorse bacterial strains that can optimize the production, reduce the contaminants, and streamline the purification procedures (Widner et al., 2005). Production and engineering of structures composed of bacterial polysaccharide have also been hampered by a lack of suitable technology. This limitation is being eroded by advances in additive manufacturing and the diversity of 3D printing technology, allowing the high speed and high throughput manufacturing of prototypes to test in a biomedical setting. There is an issue, however, with cross-platform integration whereby the specific polysaccharides used in a bioink may only be compatible with specific customized printing facilities. This can hamper the general uptake of these prospective bioinks but also makes it more attractive as a commercial venture given the intellectual property that may be associated with the production procedures.

Although the printing of various simple tissue constructs has been achieved with considerable success, the printing of complex tissue constructs and full-scale organs is still not feasible. This is due to the lack of reliable printing techniques and metabolic complexity of full- 
scale organs. A full-scale organ requires a complex and embedded vasculature and mechanically vigorous conduits associated with the host blood circulatory system. Further, the extended time required for printing of large organs risks the viability of cells within the bioink as well as in the first printed regions (Mandrycky et al., 2016). The less efficient and slow assembly of vascular features and high risk of necrosis during the early printed regions further limit the printing of large organs. These issues can be addressed to some extent through the development of highspeed and advanced printers and exploring new combinations of cells and materials with better structural features and compatibility. In response to the limitations of core 3D printing technologies (inkjet/droplet, extrusion, and laser-induced transfer), refinements, modifications, and hybrid models are developing a greater precision and mechanical control of bioprinting parameters. These models include pneumatic valve actuation, drop-on-demand micro-valve bioprinting, and cell sedimentation. These techniques facilitate the printing of stacking cellular monolayers, high output precision, and focused cell seeding for directed tissue growth (Shi et al, 2018). Scaling up is another major challenge for industrialization of 3D printing technology. With 3D bioprinting technologies forecast to reach a value of US $\$ 1.9$ billion by 2028 , more complex technologies such as microfluidics, 2-photon polymerization, and polymeric fibre electro-spinning are advancing the 3D bioprinting application markets (Colosi et al., 2016; Z. Liu et al., 2018; Miri et al., 2019).

The acceptance of 3D printed material by the general public is another major issue. Although the 3D printed constructs are produced from the same microbial polysaccharides commonly used by the people, the 3D printed constructs need to go through comprehensive evaluation prior to their general use in clinic and routine life. Such regulatory issues have delayed the wide applications of bioprinted constructs in clinical applications. To date, the 
clinical use of $3 \mathrm{D}$ printed constructs is only limited to few sporadic cases. Although the use of 3D implants varies from country to country, wider acceptance and common consensus need to be developed by establishing appropriate regulations by the regulatory bodies to enhance their industrial-scale production and general applications.

\section{Future perspectives}

The capacity for many bioactive polysaccharides to be incorporated into inks for bioprinting is dependent on further investigation of their biocompatibility and printability. Many of the bacterial polysaccharides that are currently used in bioprinting have been augmented by the addition of antimicrobials (Fürsatz et al., 2018; Matsuno et al, 2006; Sulaeva et al, 2015; K. Yue et al, 2015). However, the possibility of integrating next-generation antimicrobials, that do not actively kill bacteria, but suppress the key virulent mechanisms they use to establish infection, such as the capacity to form a biofilm, is an underexplored area and one that could have the biggest impact in the shortest time frame. Particularly, as many compounds possessing nonbiocidal antibiofilm activity have been identified as phytochemical components of food such as ajoene in garlic and coumarin in cinnamon. This means that they can be fast-tracked through further development as much of the pharmacokinetics are already determined (GutiérrezBarranquero et al., 2015; McCarthy and O’Gara, 2015; Reen et al., 2018). They are also effective in doses that are not likely to significantly impact the structural integrity of a given bioink while also reducing the probability of developing resistance as compared to the integration of traditional bactericidal antibiotics.

The key to developing the use of bacterial polysaccharides is identifying high-value

applications that can necessitate the further development of bacterial polymers as bioinks and highlight their use in the biomedical sector. Using 3D printing with bacterial polysaccharides, 
particularly those with bioactivity, to tackle the emergent threat of antibiotic resistance may be the high-value application needed to drive their development. This is being helped by the discovery of more and more polysaccharides that display antimicrobial properties but could be improved as the potential applications of bacterial polysaccharide-based bioinks has the capacity to act as a key battlefront in the war against antibiotic resistance.

\section{Acknowledgments}

R.M.C. was supported by the Brunel Research Innovation and Enterprise Fund (2018-11143), British Council/Newton Fund (2017-RLWK9-11272), and the British Society for Antimicrobial Chemotherapy (BSAC-2018-0095). This work was supported by the National Natural Science Foundation of China $(31270150,51603079,21774039)$, China Postdoctoral Science Foundation (2016M602291), and Fundamental Research Funds for Central Universities, Open Research

Fund of State Key Laboratory of Polymer Physics and Chemistry, Changchun Institute of Applied Chemistry, Chinese Academy of Sciences. 


\section{References}

Abid, Y., Casillo, A., Gharsallah, H., Joulak, I., Lanzetta, R., Corsaro, M.M., Attia, H., Azabou, S., 2018. Production and structural characterization of exopolysaccharides from newly isolated probiotic lactic acid bacteria. Int. J. Biol. Macromol. doi:10.1016/j.ijbiomac.2017.10.155

Abu Sayem, S.M., Manzo, E., Ciavatta, L., Tramice, A., Cordone, A., Zanfardino, A., De Felice, M., Varcamonti, M., 2014. Anti-biofilm activity of an exopolysaccharide from a spongeassociated strain of bacillus licheniformis, in: Biofilm Control and Antimicrobial Agents.

Adebisi, A.O., Laity, P.R., Conway, B.R., 2015. Formulation and evaluation of floating mucoadhesive alginate beads for targeting Helicobacter pylori. J. Pharm. Pharmacol. doi:10.1111/jphp.12345

Akkineni, A., Ahlfeld, T., Funk, A., Waske, A., Lode, A., Gelinsky, M., 2016. Highly Concentrated Alginate-Gellan Gum Composites for 3D Plotting of Complex Tissue Engineering Scaffolds. Polymers (Basel). doi:10.3390/polym8050170

Alboofetileh, M., Rezaei, M., Hosseini, H., Abdollahi, M., 2014. Antimicrobial activity of alginate/clay nanocomposite films enriched with essential oils against three common foodborne pathogens. Food Control. doi:10.1016/j.foodcont.2013.07.037

Aleksander Skardal, B., Zhang, Jianxing, McCoard, Lindsi, Oottamasathien, Siam, Prestwich, Glenn D, Prestwich, G D, Skardal, A., Zhang, J, McCoard, L, Oottamasathien, S, 2010. Dynamically Crosslinked Gold Nanoparticle - Hyaluronan Hydrogels. Adv. Mater 22, 4736-4740. doi:10.1002/adma.201001436

Aljohani, W., Ullah, M.W., Li, W., Shi, L., Zhang, X., Yang, G., 2018a. Three-dimensional printing of alginate-gelatin-agar scaffolds using free-form motor assisted microsyringe extrusion system. J. Polym. Res. doi:10.1007/s10965-018-1455-0

Aljohani, W., Ullah, M.W., Zhang, X., Yang, G., 2018b. Bioprinting and its applications in tissue engineering and regenerative medicine. Int. J. Biol. Macromol. 107, 261-275. doi:10.1016/j.ijbiomac.2017.08.171

Alsberg, E., Anderson, K.W., Albeiruti, A., Franceschi, R.T., Mooney, D.J., 2001. Cellinteractive alginate hydrogels for bone tissue engineering. J. Dent. Res. doi:10.1177/00220345010800111501

An, D., Chiu, A., Flanders, J.A., Song, W., Shou, D., Lu, Y.C., Grunnet, L.G., Winkel, L., Ingvorsen, C., Christophersen, N.S., Fels, J.J., Sand, F.W., Ji, Y., Qi, L., Pardo, Y., Luo, D., Silberstein, M., Fan, J., Ma, M., 2017. Designing a retrievable and scalable cell encapsulation device for potential treatment of type 1 diabetes. Proc. Natl. Acad. Sci. U. S. A. doi:10.1073/pnas.1708806115

Araujo, J. V., Davidenko, N., Danner, M., Cameron, R.E., Best, S.M., 2014. Novel porous scaffolds of $\mathrm{pH}$ responsive chitosan/carrageenan-based polyelectrolyte complexes for tissue engineering. J. Biomed. Mater. Res. - Part A 102, 4415-4426. doi:10.1002/jbm.a.35128

Ashammakhi, N., Ahadian, S., Xu, C., Montazerian, H., Ko, H., Nasiri, R., Barros, N., Khademhosseini, A., 2019. Bioinks and bioprinting technologies to make heterogeneous and biomimetic tissue constructs. Mater. Today Bio. doi:10.1016/j.mtbio.2019.100008

Ashammakhi, N., Ahadian, S., Zengjie, F., Suthiwanich, K., Lorestani, F., Orive, G., Ostrovidov, S., Khademhosseini, A., 2018. Advances and Future Perspectives in 4D Bioprinting. Biotechnol. J. doi:10.1002/biot.201800148

Azam, R.S.M., Zhang, M., Bhandari, B., Yang, C., 2018. Effect of Different Gums on Features 
of 3D Printed Object Based on Vitamin-D Enriched Orange Concentrate. Food Biophys. doi:10.1007/s11483-018-9531-X

Aziz, M.A., Cabral, J.D., Brooks, H.J.L., Moratti, S.C., Hanton, L.R., 2012. Antimicrobial Properties of a Chitosan Dextran-Based Hydrogel for Surgical Use. Antimicrob. Agents Chemother. doi:10.1128/aac.05463-11

Bajaj, P., Schweller, R.M., Khademhosseini, A., West, J.L., Bashir, R., 2014. 3D Biofabrication Strategies for Tissue Engineering and Regenerative Medicine. Annu. Rev. Biomed. Eng. 16, 247-276. doi:10.1146/annurev-bioeng-071813-105155

Bendaoud, M., Vinogradov, E., Balashova, N. V., Kadouri, D.E., Kachlany, S.C., Kaplan, J.B., 2011. Broad-spectrum biofilm inhibition by Kingella kingae exopolysaccharide. J. Bacteriol. doi:10.1128/JB.00311-11

Bernal, P., Llamas, M.A., 2012. Promising biotechnological applications of antibiofilm exopolysaccharides. Microb. Biotechnol. doi:10.1111/j.1751-7915.2012.00359.x

Bertassoni, Luiz E, Cardoso, J.C., Manoharan, V., Cristino, A.L., Bhise, N.S., Araujo, W.A., Zorlutuna, P., Vrana, N.E., Ghaemmaghami, A.M., Dokmeci, M.R., Khademhosseini, A., 2014. Direct-write bioprinting of cell-laden methacrylated gelatin hydrogels. Biofabrication 6, 024105. doi:10.1088/1758-5082/6/2/024105

Bertassoni, Luiz E., Cecconi, M., Manoharan, V., Nikkhah, M., Hjortnaes, J., Cristino, A.L., Barabaschi, G., Demarchi, D., Dokmeci, M.R., Yang, Y., Khademhosseini, A., 2014. Hydrogel bioprinted microchannel networks for vascularization of tissue engineering constructs. Lab Chip 14, 2202-2211. doi:10.1039/C4LC00030G

Bian, S., He, M., Sui, J., Cai, H., Sun, Y., Liang, J., Fan, Y., 2016a. Colloids and Surfaces B: Biointerfaces The self-crosslinking smart hyaluronic acid hydrogels as injectable threedimensional scaffolds for cells culture. Colloids Surfaces B Biointerfaces 140, 392-402. doi:10.1016/j.colsurfb.2016.01.008

Bian, S., He, M., Sui, J., Cai, H., Sun, Y., Liang, J., Fan, Y., Zhang, X., 2016b. The selfcrosslinking smart hyaluronic acid hydrogels as injectable three-dimensional scaffolds for cells culture. Colloids Surfaces B Biointerfaces. doi:10.1016/j.colsurfb.2016.01.008

Brian-Jaisson, F., Molmeret, M., Fahs, A., Guentas-Dombrowsky, L., Culioli, G., Blache, Y., Cérantola, S., Ortalo-Magné, A., 2016. Characterization and anti-biofilm activity of extracellular polymeric substances produced by the marine biofilm-forming bacterium pseudoalteromonas ulvae strain TC14. Biofouling. doi:10.1080/08927014.2016.1164845

Cárdenas-Triviño, G., Ruiz-Parra, M., Vergara-González, L., Ojeda-Oyarzún, J., Solorzano, G., 2017. Synthesis and Bactericidal Properties of Hyaluronic Acid Doped with Metal Nanoparticles. J. Nanomater. doi:10.1155/2017/9573869

Catros, S., Guillotin, B., Ba????kov??, M., Fricain, J.C., Guillemot, F., 2011. Effect of laser energy, substrate film thickness and bioink viscosity on viability of endothelial cells printed by laser-assisted bioprinting, in: Applied Surface Science. pp. 5142-5147. doi:10.1016/j.apsusc.2010.11.049

Chapot-Chartier, M.P., 2014. Interactions of the cell-wall glycopolymers of lactic acid bacteria with their bacteriophages. Front. Microbiol. doi:10.3389/fmicb.2014.00236

Chen, M., Liang, P., 2017. Synthesis and antibacterial activity of quaternized curdlan. Polym. Bull. doi:10.1007/s00289-017-1951-0

Colosi, C., Shin, S.R., Manoharan, V., Massa, S., Costantini, M., Barbetta, A., Dokmeci, M.R., Dentini, M., Khademhosseini, A., 2016. Microfluidic Bioprinting of Heterogeneous 3D Tissue Constructs Using Low-Viscosity Bioink. Adv. Mater. 28, 677-684. 
doi:10.1002/adma.201503310

Cornelissen, D.-J., Faulkner-Jones, A., Shu, W., 2017. Current developments in 3D bioprinting for tissue engineering. Curr. Opin. Biomed. Eng. 2, 76-82. doi:10.1016/j.cobme.2017.05.004

Czaja, W.K., Young, D.J., Kawecki, M., Brown, R.M., 2007. The future prospects of microbial cellulose in biomedical applications. Biomacromolecules. doi:10.1021/bm060620d

De Cicco, F., Reverchon, E., Adami, R., Auriemma, G., Russo, P., Calabrese, E.C., Porta, A., Aquino, R.P., Del Gaudio, P., 2014. In situ forming antibacterial dextran blend hydrogel for wound dressing: SAA technology vs. spray drying. Carbohydr. Polym. doi:10.1016/j.carbpo1.2013.10.067

de Oliveira, C.R., 2012. Bacterial Cellulose Membranes Constitute Biocompatible Biomaterials for Mesenchymal and Induced Pluripotent Stem Cell Culture and Tissue Engineering. J. Tissue Sci. Eng. S11. doi:10.4172/2157-7552.S11-005

Derakhshanfar, S., Mbeleck, R., Xu, K., Zhang, X., Zhong, W., Xing, M., 2018. 3D bioprinting for biomedical devices and tissue engineering: A review of recent trends and advances. Bioact. Mater. 3, 144-156. doi:10.1016/j.bioactmat.2017.11.008

Dhoot, N.O., Tobias, C.A., Fischer, I., Wheatley, M.A., 2004. Peptide-modified alginate surfaces as a growth permissive substrate for neurite outgrowth. J. Biomed. Mater. Res. - Part A. doi:10.1002/jbm.a.30103

Di, Z., Shi, Z., Ullah, M.W., Li, S., Yang, G., 2017. A transparent wound dressing based on bacterial cellulose whisker and poly(2-hydroxyethyl methacrylate). Int. J. Biol. Macromol. 105, 638-644. doi:10.1016/j.ijbiomac.2017.07.075

Donati, I., Paoletti, S., 2009. Material Properties of Alginates. doi:10.1007/978-3-540-92679-5_1

Dos Santos Goncalves, M., Delattre, C., Balestrino, D., Charbonnel, N., Elboutachfaiti, R., Wadouachi, A., Badel, S., Bernardi, T., Michaud, P., Forestier, C., 2014. Anti-biofilm activity: A function of Klebsiella pneumoniae capsular polysaccharide. PLoS One. doi:10.1371/journal.pone.0099995

Douglas, T.E.L., Dziadek, M., Gorodzha, S., Lišková, J., Brackman, G., Vanhoorne, V., Vervaet, C., Balcaen, L., del Rosario Florez Garcia, M., Boccaccini, A.R., Weinhardt, V., Baumbach, T., Vanhaecke, F., Coenye, T., Bačáková, L., Surmeneva, M.A., Surmenev, R.A., CholewaKowalska, K., Skirtach, A.G., 2018. Novel injectable gellan gum hydrogel composites incorporating $\mathrm{Zn}$ - and Sr-enriched bioactive glass microparticles: High-resolution X-ray microcomputed tomography, antibacterial and in vitro testing. J. Tissue Eng. Regen. Med. doi:10.1002/term.2654

Dounighi, N.M., Shahcheraghi, F., Razzaghi-Abyaneh, M., Nofeli, M., Zolfagharian, H., 2017. A New Vaccine Delivery Vehicle and Adjuvant Candidate: Bordetella pertussis Inactivated Whole Cells Entrapped in Alginate Microspheres. Curr. Pharm. Des. doi:10.2174/1381612823666170112124303

Dourado, F., Gama, M., Rodrigues, A.C., 2017. A Review on the toxicology and dietetic role of bacterial cellulose. Toxicol. Reports. doi:10.1016/j.toxrep.2017.09.005

Du, Z., Li, N., Hua, Y., Shi, Y., Bao, C., Zhang, H., Yang, Y., Lin, Q., Zhu, L., 2017. Physiological $\mathrm{pH}$-dependent gelation for $3 \mathrm{D}$ printing based on the phase separation of gelatin and oxidized dextran. Chem. Commun. doi:10.1039/c7cc08225h

El-Hoseny, S.M., Basmaji, P., Olyveira, G.M. de, Costa, L.M.M., Alwahedi, A.M., Oliveira, J.D. da C., Francozo, G.B., 2015. Natural ECM-Bacterial Cellulose Wound Healing-Dubai Study. J. Biomater. Nanobiotechnol. doi:10.4236/jbnb.2015.64022 
Elizalde-Peña, E.A., Quintero-Ortega, I.A., Zárate-Triviño, D.G., Nuño-Licona, A., Gough, J., Sanchez, I.C., Medina, D.I., Luna-Barcenas, G., 2017. (Chitosan-g-glycidyl methacrylate)xanthan hydrogel implant in Wistar rats for spinal cord regeneration. Mater. Sci. Eng. C 78, 892-900. doi:10.1016/j.msec.2017.03.005

Endler, A., Sánchez-Rodríguez, C., Persson, S., 2010. Cellulose squeezes through. Nat. Chem. Biol. 6, 883-884. doi:10.1038/nchembio.480

Ferris, C.J., Gilmore, K.J., Wallace, G.G., Panhuis, M. In Het, 2013. Modified gellan gum hydrogels for tissue engineering applications. Soft Matter. doi:10.1039/c3sm27389j

Flemming, H.C., Wingender, J., 2001. Relevance of microbial extracellular polymeric substances (EPSs) - Part II: Technical aspcets, in: Water Science and Technology.

Fontana, J.D., De Souza, A.M., Fontana, C.K., Torriani, I.L., Moreschi, J.C., Gallotti, B.J., De Souza, S.J., Narcisco, G.P., Bichara, J.A., Farah, L.F.X., 1990. Acetobacter cellulose pellicle as a temporary skin substitute. Appl. Biochem. Biotechnol. doi:10.1007/BF02920250

Freeman, F.E., Kelly, D.J., 2017. Tuning alginate bioink stiffness and composition for controlled growth factor delivery and to spatially direct MSC Fate within bioprinted tissues. Sci. Rep. doi:10.1038/s41598-017-17286-1

Fu, L., Zhang, J., Yang, G., 2013. Present status and applications of bacterial cellulose-based materials for skin tissue repair. Carbohydr. Polym. doi:10.1016/j.carbpol.2012.10.071

Fürsatz, M., Skog, M., Sivlér, P., Palm, E., Aronsson, C., Skallberg, A., Greczynski, G., Khalaf, H., Bengtsson, T., Aili, D., 2018. Functionalization of bacterial cellulose wound dressings with the antimicrobial peptide $\epsilon$-poly-L-Lysine. Biomed. Mater. doi:10.1088/1748$605 X / a a 9486$

Gao, X., Shi, Z., Liu, C., Yang, G., Silberschmidt, V. V., 2016. Fracture Behaviour of Bacterial Cellulose Hydrogel: Microstructural Effect, in: Procedia Structural Integrity. doi:10.1016/j.prostr.2016.06.158

Gao, X., Sozumert, E., Shi, Z., Yang, G., Silberschmidt, V. V., 2017. Assessing stiffness of nanofibres in bacterial cellulose hydrogels: Numerical-experimental framework. Mater. Sci. Eng. C. doi:10.1016/j.msec.2017.03.231

Gattani, S.G., Savaliya, P.J., Belgamwar, V.S., 2010. Floating-mucoadhesive beads of clarithromycin for the treatment of Helicobacter pylori infection. Chem. Pharm. Bull. doi:10.1248/cpb.58.782

Glicklis, R., Shapiro, L., Agbaria, R., Merchuk, J.C., Cohen, S., 2000. Hepatocyte behavior within three-dimensional porous alginate scaffolds. Biotechnol. Bioeng. doi:10.1002/(SICI)1097-0290(20000205)67:3<344::AID-BIT11>3.0.CO;2-2

Gopinathan, J., Noh, I., 2018. Recent trends in bioinks for 3D printing. Biomater. Res. doi:10.1186/s40824-018-0122-1

Gou, M., Qu, X., Zhu, W., Xiang, M., Yang, J., Zhang, K., Wei, Y., Chen, S., 2014. Bio-inspired detoxification using 3D-printed hydrogel nanocomposites. Nat. Commun. 5. doi:10.1038/ncomms4774

Gudapati, H., Dey, M., Ozbolat, I., 2016. A comprehensive review on droplet-based bioprinting: Past, present and future. Biomaterials. doi:10.1016/j.biomaterials.2016.06.012

Gupta, P., Diwan, B., 2017. Bacterial Exopolysaccharide mediated heavy metal removal: A Review on biosynthesis, mechanism and remediation strategies. Biotechnol. Reports. doi:10.1016/j.btre.2016.12.006

Gutiérrez-Barranquero, J.A., Reen, F.J., McCarthy, R.R., O’Gara, F., 2015. Deciphering the role 
of coumarin as a novel quorum sensing inhibitor suppressing virulence phenotypes in bacterial pathogens. Appl. Microbiol. Biotechnol. doi:10.1007/s00253-015-6436-1

Halib, N., Ahmad, I., Grassi, M., Grassi, G., 2019. The remarkable three-dimensional network structure of bacterial cellulose for tissue engineering applications. Int. J. Pharm. 566, 631640. doi:10.1016/j.ijpharm.2019.06.017

Hay, I.D., Rehman, Z.U., Moradali, M.F., Wang, Y., Rehm, B.H.A., 2013. Microbial alginate production, modification and its applications. Microb. Biotechnol. doi:10.1111/17517915.12076

He, F., Yang, Y., Yang, G., Yu, L., 2010. Studies on antibacterial activity and antibacterial mechanism of a novel polysaccharide from Streptomyces virginia H03. Food Control 21, 1257-1262. doi:10.1016/j.foodcont.2010.02.013

Hillberg, A.L., Oudshoorn, M., Lam, J.B.B., Kathirgamanathan, K., 2015. Encapsulation of porcine pancreatic islets within an immunoprotective capsule comprising methacrylated glycol chitosan and alginate. J. Biomed. Mater. Res. - Part B Appl. Biomater. doi:10.1002/jbm.b.33185

Hinton, T.J., Jallerat, Q., Palchesko, R.N., Park, J.H., Grodzicki, M.S., Shue, H.-J., Ramadan, M.H., Hudson, A.R., Feinberg, A.W., 2015. Three-dimensional printing of complex biological structures by freeform reversible embedding of suspended hydrogels. Sci. Adv. 1, e1500758-e1500758. doi:10.1126/sciadv.1500758

Hölzl, K., Lin, S., Tytgat, L., Van Vlierberghe, S., Gu, L., Ovsianikov, A., 2016. Bioink properties before, during and after 3D bioprinting. Biofabrication 8, 032002. doi:10.1088/1758-5090/8/3/032002

Hornick, J.F., Rajan, K., 2015. Intellectual property in 3D printing and nanotechnology, 3D Bioprinting and Nanotechnology in Tissue Engineering and Regenerative Medicine. Elsevier Inc. doi:10.1016/B978-0-12-800547-7/00016-3

Hospodiuk, M., Dey, M., Sosnoski, D., Ozbolat, I.T., 2017. The bioink: A comprehensive review on bioprintable materials. Biotechnol. Adv. doi:10.1016/j.biotechadv.2016.12.006

Huang, T.Q., Qu, X., Liu, J., Chen, S., 2014. 3D printing of biomimetic microstructures for cancer cell migration. Biomed. Microdevices 16, 127-132. doi:10.1007/s10544-013-9812-6

Irie, Y., Borlee, B.R., O'Connor, J.R., Hill, P.J., Harwood, C.S., Wozniak, D.J., Parsek, M.R., 2012. Self-produced exopolysaccharide is a signal that stimulates biofilm formation in Pseudomonas aeruginosa. Proc. Natl. Acad. Sci. U. S. A. doi:10.1073/pnas.1217993109

Irie, Y., Roberts, A.E.L., Kragh, K.N., Gordon, V.D., Hutchison, J., Allen, R.J., Melaugh, G., Bjarnsholt, T., West, S.A., Diggle, S.P., 2017. The Pseudomonas aeruginosa PSL polysaccharide is a social but noncheatable trait in biofilms. MBio. doi:10.1128/mBio.00374-17

Ismail, N.A., Amin, K.A.M., Majid, F.A.A., Razali, M.H., 2019. Gellan gum incorporating titanium dioxide nanoparticles biofilm as wound dressing: Physicochemical, mechanical, antibacterial properties and wound healing studies. Mater. Sci. Eng. C. doi:10.1016/j.msec.2019.109770

Jia, J., Richards, D.J., Pollard, S., Tan, Y., Rodriguez, J., Visconti, R.P., Trusk, T.C., Yost, M.J., Yao, H., Markwald, R.R., Mei, Y., 2014. Engineering alginate as bioink for bioprinting. Acta Biomater. 10, 4323-4331. doi:10.1016/j.actbio.2014.06.034

Jiang, P., Li, J., Han, F., Duan, G., Lu, X., Gu, Y., Yu, W., 2011. Antibiofilm activity of an exopolysaccharide from marine bacterium Vibrio sp. QY101. PLoS One. doi:10.1371/journal.pone.0018514 
Jovic, T.H., Kungwengwe, G., Mills, A.C., Whitaker, I.S., 2019. Plant-Derived Biomaterials: A Review of 3D Bioprinting and Biomedical Applications. Front. Mech. Eng. 5. doi:10.3389/fmech.2019.00019

Jung, J.Y., Khan, T., Park, J.K., Chang, H.N., 2007. Production of bacterial cellulose by Gluconacetobacter hansenii using a novel bioreactor equipped with a spin filter. Korean J. Chem. Eng. 24, 265-271. doi:10.1007/s11814-007-5058-4

Junter, G.A., Thébault, P., Lebrun, L., 2016. Polysaccharide-based antibiofilm surfaces. Acta Biomater. doi:10.1016/j.actbio.2015.11.010

Kang, D., Ahn, G., Kim, D., Kang, H.W., Yun, S., Yun, W.S., Shim, J.H., Jin, S., 2018. Pre-set extrusion bioprinting for multiscale heterogeneous tissue structure fabrication. Biofabrication. doi:10.1088/1758-5090/aac70b

Kanmani, P., Satish kumar, R., Yuvaraj, N., Paari, K.A., Pattukumar, V., Arul, V., 2011. Production and purification of a novel exopolysaccharide from lactic acid bacterium Streptococcus phocae PI80 and its functional characteristics activity in vitro. Bioresour. Technol. doi:10.1016/j.biortech.2010.12.118

Karwacki, M.T., Kadouri, D.E., Bendaoud, M., Izano, E.A., Sampathkumar, V., Inzana, T.J., Kaplan, J.B., 2013. Antibiofilm Activity of Actinobacillus pleuropneumoniae Serotype 5 Capsular Polysaccharide. PLoS One. doi:10.1371/journal.pone.0063844

Kavita, K., Singh, V.K., Mishra, A., Jha, B., 2014. Characterisation and anti-biofilm activity of extracellular polymeric substances from Oceanobacillus iheyensis. Carbohydr. Polym. doi:10.1016/j.carbpol.2013.08.099

Khan, S., Ul-Islam, M., Ikram, M., Islam, S.U., Ullah, M.W., Israr, M., Jang, J.H., Yoon, S., Park, J.K., 2018a. Preparation and structural characterization of surface modified microporous bacterial cellulose scaffolds: A potential material for skin regeneration applications in vitro and in vivo. Int. J. Biol. Macromol. 117, 1200-1210. doi:10.1016/j.ijbiomac.2018.06.044

Khan, S., Ul-Islam, M., Khattak, W.A., Ullah, M.W., Yu, B., Park, J.K., 2015. Enhanced bioethanol production via simultaneous saccharification and fermentation through a cell free enzyme system prepared by disintegration of waste of beer fermentation broth. Korean J. Chem. Eng. 32. doi:10.1007/s11814-014-0242-9

Khan, S., Ul-Islam, M., Ullah, M.W., Israr, M., Jang, J.H., Park, J.K., 2018b. Nano-gold assisted highly conducting and biocompatible bacterial cellulose-PEDOT:PSS films for biologydevice interface applications. Int. J. Biol. Macromol. doi:10.1016/j.ijbiomac.2017.09.064

Khanna, O., Larson, J.C., Moya, M.L., Opara, E.C., Brey, E.M., 2012. Generation of alginate microspheres for biomedical applications. J. Vis. Exp. doi:10.3791/3388

Kim, Y., Oh, S., Kim, S.H., 2009. Released exopolysaccharide (r-EPS) produced from probiotic bacteria reduce biofilm formation of enterohemorrhagic Escherichia coli O157:H7. Biochem. Biophys. Res. Commun. 379, 324-329. doi:10.1016/j.bbrc.2008.12.053

Kim, Y., Ullah, M.W., Ul-Islam, M., Khan, S., Jang, J.H., Park, J.K., 2019. Self-assembly of biocellulose nanofibrils through intermediate phase in a cell-free enzyme system. Biochem. Eng. J. 142, 135-144. doi:10.1016/j.bej.2018.11.017

Kolesky, D.B., Homan, K.A., Skylar-Scott, M.A., Lewis, J.A., 2016. Three-dimensional bioprinting of thick vascularized tissues. Proc. Natl. Acad. Sci. U. S. A. 113, 3179-84. doi:10.1073/pnas.1521342113

Kolesky, D.B., Truby, R.L., Gladman, A.S., Busbee, T.A., Homan, K.A., Lewis, J.A., 2014. 3D bioprinting of vascularized, heterogeneous cell-laden tissue constructs. Adv. Mater. 26, 
3124-3130. doi:10.1002/adma.201305506

Koo, L.Y., Irvine, D.J., Mayes, A.M., Lauffenburger, D.A., Griffith, L.G., 2002. Co-regulation of cell adhesion by nanoscale RGD organization and mechanical stimulus. J. Cell Sci.

Kuzmenko, V., Karabulut, E., Pernevik, E., Enoksson, P., Gatenholm, P., 2018. Tailor-made conductive inks from cellulose nanofibrils for 3D printing of neural guidelines. Carbohydr. Polym. doi:10.1016/j.carbpol.2018.01.097

Lamboni, L., Xu, C., Clasohm, J., Yang, J., Saumer, M., Schäfer, K.H., Yang, G., 2019. Silk sericin-enhanced microstructured bacterial cellulose as tissue engineering scaffold towards prospective gut repair. Mater. Sci. Eng. C. doi:10.1016/j.msec.2019.04.043

Lee, J., Lee, K.Y., 2009. Local and sustained vascular endothelial growth factor delivery for angiogenesis using an injectable system. Pharm. Res. doi:10.1007/s11095-009-9884-4

Lee, K.J., Lee, M.A., Hwang, W., Park, H., Lee, K.H., 2016. Deacylated lipopolysaccharides inhibit biofilm formation by Gram-negative bacteria. Biofouling. doi:10.1080/08927014.2016.1193595

Lee, K.Y., Kong, H.J., Mooney, D.J., 2008. Quantifying interactions between cell receptors and adhesion ligand-modified polymers in solution. Macromol. Biosci. doi:10.1002/mabi.200700169

Lee, K.Y., Mooney, D.J., 2012. Alginate: Properties and biomedical applications. Prog. Polym. Sci. doi:10.1016/j.progpolymsci.2011.06.003

Lee, S.H., Lim, Y.M., Jeong, S.I., An, S.J., Kang, S.S., Jeong, C.M., Huh, J.B., 2015. The effect of bacterial cellulose membrane compared with collagen membrane on guided bone regeneration. J. Adv. Prosthodont. doi:10.4047/jap.2015.7.6.484

Li, J., Chen, M., Fan, X., Zhou, H., 2016. Recent advances in bioprinting techniques: Approaches, applications and future prospects. J. Transl. Med. doi:10.1186/s12967-0161028-0

Li, S., Jasim, A., Zhao, W., Fu, L., Ullah, M.W., Shi, Z., Yang, G., 2018. Fabrication of pHelectroactive Bacterial Cellulose/Polyaniline Hydrogel for the Development of a Controlled Drug Release System. ES Mater. Manuf. 1, 41-49. doi:10.30919/esmm5fl 20

Li, S.W., Sheng, G.P., Cheng, Y.Y., Yu, H.Q., 2016. Redox properties of extracellular polymeric substances (EPS) from electroactive bacteria. Sci. Rep. doi:10.1038/srep39098

Li, W., Ji, J., Rui, X., Yu, J., Tang, W., Chen, X., Jiang, M., Dong, M., 2014. Production of exopolysaccharides by Lactobacillus helveticus MB2-1 and its functional characteristics in vitro. LWT - Food Sci. Technol. doi:10.1016/j.lwt.2014.06.063

Li, Y., Li, Q., Hao, D., Jiang, D., Luo, Y., Liu, Y., Zhao, Z., 2015. Production, purification, and antibiofilm activity of a novel exopolysaccharide from Arthrobacter sp. B4. Prep. Biochem. Biotechnol. doi:10.1080/10826068.2014.907180

Limoli, D.H., Jones, C.J., Wozniak, D.J., 2015. Bacterial Extracellular Polysaccharides in Biofilm Formation and Function. Microbiol. Spectr. 3. doi:10.1128/microbiolspec.MB0011-2014

Liu, J., Zhang, Z., Qiu, L., Zhang, F., Xu, X., Wei, H., Tao, H. 2017. Characterization and bioactivities of the exopolysaccharide from a probiotic strain of Lactobacillus plantarum WLPL04. Journal of Dairy Sci,Volume 100, Issue 9, p 6895-6905.

Liu, J., Xu, Z., Guo, Z., Zhao, Z., Zhao, Y., Wang, X., 2018. Structural investigation of a polysaccharide from the mycelium of Enterobacter cloacae and its antibacterial activity against extensively drug-resistant E. cloacae producing SHV-12 extended-spectrum $\beta$ lactamase. Carbohydr. Polym. doi:10.1016/j.carbpol.2018.04.114 
Liu, Z., Zhang, M., Bhandari, B., 2018. Effect of gums on the rheological, microstructural and extrusion printing characteristics of mashed potatoes. Int. J. Biol. Macromol. doi:10.1016/j.ijbiomac.2018.06.048

Llacua, L.A., de Haan, B.J., de Vos, P., 2018. Laminin and collagen IV inclusion in immunoisolating microcapsules reduces cytokine-mediated cell death in human pancreatic islets. J. Tissue Eng. Regen. Med. doi:10.1002/term.2472

Loh, G.H., Pei, E., Harrison, D., Monzón, M.D., 2018. An overview of functionally graded additive manufacturing. Addit. Manuf. doi:10.1016/j.addma.2018.06.023

López-Pliego, L., García-Ramírez, L., Cruz-Gómez, E.A., Domínguez-Ojeda, P., LópezPastrana, A., Fuentes-Ramírez, L.E., Núñez, C., Castañeda, M., 2018. Transcriptional Study of the RsmZ-sRNAs and Their Relationship to the Biosynthesis of Alginate and Alkylresorcinols in Azotobacter vinelandii. Mol. Biotechnol. doi:10.1007/s12033-0180102-7

Lozano, R., Stevens, L., Thompson, B.C., Gilmore, K.J., Gorkin, R., Stewart, E.M., in het Panhuis, M., Romero-Ortega, M., Wallace, G.G., 2015. 3D printing of layered brain-like structures using peptide modified gellan gum substrates. Biomaterials. doi:10.1016/j.biomaterials.2015.07.022

Madzovska-Malagurski, I., Vukasinovic-Sekulic, M., Kostic, D., Levic, S., 2016. Towards antimicrobial yet bioactive $\mathrm{Cu}$-alginate hydrogels. Biomed. Mater. doi:10.1088/17486041/11/3/035015

Maestrelli, F., Mura, P., González-Rodríguez, M.L., Cózar-Bernal, M.J., Rabasco, A.M., Di Cesare Mannelli, L., Ghelardini, C., 2017. Calcium alginate microspheres containing metformin hydrochloride niosomes and chitosomes aimed for oral therapy of type 2 diabetes mellitus. Int. J. Pharm. doi:10.1016/j.ijpharm.2017.07.083

Mandrycky, C., Wang, Z., Kim, K., Kim, D.H., 2016. 3D bioprinting for engineering complex tissues. Biotechnol. Adv. doi:10.1016/j.biotechadv.2015.12.011

Maneerung, T., Tokura, S., Rujiravanit, R., 2008. Impregnation of silver nanoparticles into bacterial cellulose for antimicrobial wound dressing. Carbohydr. Polym. doi:10.1016/j.carbpol.2007.07.025

Maria Manzine Costa, L., Molina de Olyveira, G., Basmaji, P., Xavier Filho, L., 2012. Nanopores Structure in Electrospun Bacterial Cellulose. J. Biomater. Nanobiotechnol. doi:10.4236/jbnb.2012.31012

Markstedt, K., Mantas, A., Tournier, I., Martínez Ávila, H., Hägg, D., Gatenholm, P., 2015. 3D bioprinting human chondrocytes with nanocellulose-alginate bioink for cartilage tissue engineering applications. Biomacromolecules 16, 1489-1496. doi:10.1021/acs.biomac.5b00188

Martínez Ávila, H., Schwarz, S., Rotter, N., Gatenholm, P., 2016. 3D bioprinting of human chondrocyte-laden nanocellulose hydrogels for patient-specific auricular cartilage regeneration. Bioprinting. doi:10.1016/j.bprint.2016.08.003

Matsuno, H., Yudoh, K., Hashimoto, M., Himeda, Y., Miyoshi, T., Yoshida, K., Kano, S., 2006. A new antibacterial carrier of hyaluronic acid gel. J. Orthop. Sci. doi:10.1007/s00776-0061059-0

McCarthy, R.R., Mazon-Moya, M.J., Moscoso, J.A., Hao, Y., Lam, J.S., Bordi, C., Mostowy, S., Filloux, A., 2017. Cyclic-di-GMP regulates lipopolysaccharide modification and contributes to Pseudomonas aeruginosa immune evasion. Nat. Microbiol. doi:10.1038/nmic robiol.2017.27 
McCarthy, R.R., Mooij, M.J., Reen, F.J., Lesouhaitier, O., O’Gara, F., 2014. A new regulator of pathogenicity (bvlR) is required for full virulence and tight microcolony formation in Pseudomonas aeruginosa. Microbiol. (United Kingdom). doi:10.1099/mic.0.075291-0

McCarthy, R.R., O'Gara, F., 2015. The impact of phytochemicals present in the diet on microbial signalling in the human gut. J. Funct. Foods. doi:10.1016/j.jff.2015.02.032

McCarthy, R.R., Ullah, M.W., Pei, E., Yang, G., 2019. Antimicrobial Inks: The Anti-Infective Applications of Bioprinted Bacterial Polysaccharides. Trends Biotechnol. xx, 1-4. doi:10.1016/j.tibtech.2019.05.004

Miller, J.S., Stevens, K.R., Yang, M.T., Baker, B.M., Nguyen, D.-H.T., Cohen, D.M., Toro, E., Chen, A.A., Galie, P.A., Yu, X., Chaturvedi, R., Bhatia, S.N., Chen, C.S., 2012. Rapid casting of patterned vascular networks for perfusable engineered three-dimensional tissues. Nat. Mater. 11, 768-774. doi:10.1038/nmat3357

Miri, A.K., Mirzaee, I., Hassan, S., Mesbah Oskui, S., Nieto, D., Khademhosseini, A., Zhang, Y.S., 2019. Effective bioprinting resolution in tissue model fabrication. Lab Chip. doi:10.1039/c8lc01037d

Mistou, M.Y., Sutcliffe, I.C., Van Sorge, N.M., 2016. Bacterial glycobiology: Rhamnosecontaining cell wall polysaccharides in gram-positive bacteria. FEMS Microbiol. Rev. doi:10.1093/femsre/fuw006

Moradali, M.F., Ghods, S., Rehm, B.H.A., 2018. Alginate Biosynthesis and Biotechnological Production, in: Rehm, B.H.A., Moradali, M.F. (Eds.), Alginates and Their Biomedical Applications. Springer Singapore, Singapore, pp. 1-25. doi:10.1007/978-981-10-6910-9_1

Moscovici, M., 2015. Present and future medical applications of microbial exopolysaccharides. Front. Microbiol. doi:10.3389/fmicb.2015.01012

Murphy, S. V, Atala, A., 2014. 3D bioprinting of tissues and organs. Nat. Biotechnol. 32, 773785. doi:10.1038/nbt.2958

Narayanan, L.K., Huebner, P., Fisher, M.B., Spang, J.T., Starly, B., Shirwaiker, R.A., 2016. 3DBioprinting of Polylactic Acid (PLA) Nanofiber-Alginate Hydrogel Bioink Containing Human Adipose-Derived Stem Cells. ACS Biomater. Sci. Eng. doi:10.1021/acsbiomaterials.6b00196

Ning, L., Sun, H., Lelong, T., Guilloteau, R., Zhu, N., Schreyer, D.J., Chen, X., 2018. 3D bioprinting of scaffolds with living Schwann cells for potential nerve tissue engineering applications. Biofabrication. doi:10.1088/1758-5090/aacd30

Orloff, N.D., Truong, C., Cira, N., Koo, S., Hamilton, A., Choi, S., Wu, V., Riedel-Kruse, I.H., 2014. Integrated bioprinting and imaging for scalable, networkable desktop experimentation. RSC Adv. 4, 34721. doi:10.1039/C4RA05932H

Osmokrovic, A., Jancic, I., Vunduk, J., Petrovic, P., Milenkovic, M., Obradovic, B., 2018. Achieving high antimicrobial activity: Composite alginate hydrogel beads releasing activated charcoal with an immobilized active agent. Carbohydr. Polym. doi:10.1016/j.carbpol.2018.05.045

Otterlei, M., Østgaard, K., Skjåk-Bræk, G., SmidsrØd, O., Soon-Shiong, P., Espevik, T., 1991. Induction of Cytokine Production from Human Monocytes Stimulated with Alginate. J. Immunother. doi:10.1097/00002371-199108000-00007

Ozbolat, I.T., Chen, H., Yu, Y., 2014. Development of "Multi-arm Bioprinter" for hybrid biofabrication of tissue engineering constructs. Robot. Comput. Integr. Manuf. 30, 295-304. doi:10.1016/j.rcim.2013.10.005

Ozbolat, I.T., Yu, Y., 2013. Bioprinting toward organ fabrication: Challenges and future trends. 
IEEE Trans. Biomed. Eng. 60, 691-699. doi:10.1109/TBME.2013.2243912

Pandin, C., Le Coq, D., Canette, A., Aymerich, S., Briandet, R., 2017. Should the biofilm mode of life be taken into consideration for microbial biocontrol agents? Microb. Biotechnol. doi:10.1111/1751-7915.12693

Paolicelli, P., Petralito, S., Varani, G., Nardoni, M., Pacelli, S., Di Muzio, L., Tirillò, J., Bartuli, C., Cesa, S., Casadei, M.A., Adrover, A., 2018. Effect of glycerol on the physical and mechanical properties of thin gellan gum films for oral drug delivery. Int. J. Pharm. 547, 226-234. doi:10.1016/j.ijpharm.2018.05.046

Park, J.K., Shim, J.H., Kang, K.S., Yeom, J., Jung, H.S., Kim, J.Y., Lee, K.H., Kim, T.H., Kim, S.Y., Cho, D.W., Hahn, S.K., 2011. Solid free-form fabrication of tissue-engineering scaffolds with a poly(lactic-co-glycolic acid) grafted hyaluronic acid conjugate encapsulating and intact bone morphogenetic protein-2/poly(ethylene glycol) complex. Adv. Funct. Mater. 21, 2906-2912. doi:10.1002/adfm.201100612

Park, J.Y., Jang, J., Kang, H.W., 2018. 3D Bioprinting and its application to organ-on-a-chip. Microelectron. Eng. doi:10.1016/j.mee.2018.08.004

Pasteur, L., 1861. On the viscous fermentation and the butyrous fermentation. Bull.Soc.Chim 11, 30-31.

Pescosolido, L., Schuurman, W., Malda, J., Matricardi, P., Alhaique, F., Coviello, T., Van Weeren, P.R., Dhert, W.J.A., Hennink, W.E., Vermonden, T., 2011a. Hyaluronic acid and dextran-based semi-IPN hydrogels as biomaterials for bioprinting. Biomacromolecules 12, 1831-1838. doi:10.1021/bm200178w

Pescosolido, L., Schuurman, W., Malda, J., Matricardi, P., Alhaique, F., Coviello, T., Van Weeren, P.R., Dhert, W.J.A., Hennink, W.E., Vermonden, T., 2011b. Hyaluronic acid and dextran-based semi-IPN hydrogels as biomaterials for bioprinting. Biomacromolecules. doi:10.1021/bm200178w

Peteiro, C., 2018. Alginate Production from Marine Macroalgae, with Emphasis on Kelp Farming. pp. 27-66. doi:10.1007/978-981-10-6910-9_2

Posadowska, U., Brzychczy-Wloch, M., Pamula, E., 2016. Injectable gellan gum-based nanoparticles-loaded system for the local delivery of vancomycin in osteomyelitis treatment. J. Mater. Sci. Mater. Med. 27, 9. doi:10.1007/s10856-015-5604-2

Powell, L.C., Pritchard, M.F., Ferguson, E.L., Powell, K.A., Patel, S.U., Rye, P.D., Sakellakou, S.M., Buurma, N.J., Brilliant, C.D., Copping, J.M., Menzies, G.E., Lewis, P.D., Hill, K.E., Thomas, D.W., 2018. Targeted disruption of the extracellular polymeric network of Pseudomonas aeruginosa biofilms by alginate oligosaccharides. npj Biofilms Microbiomes. doi:10.1038/s41522-018-0056-3

Pradeepa, Shetty, A.D., Matthews, K., Hegde, A.R., Akshatha, B., Mathias, A.B., Mutalik, S., Vidya, S.M., 2016. Multidrug resistant pathogenic bacterial biofilm inhibition by Lactobacillus plantarum exopolysaccharide. Bioact. Carbohydrates Diet. Fibre. doi:10.1016/j.bcdf.2016.06.002

Qin, Z., Yang, L., Qu, D., Molin, S., Tolker-Nielsen, T., 2009. Pseudomonas aeruginosa extracellular products inhibit staphylococcal growth, and disrupt established biofilms produced by staphylococcus epidermidis. Microbiology. doi:10.1099/mic.0.028001-0

Ramsey, D.M., Wozniak, D.J., 2005. Understanding the control of Pseudomonas aeruginosa alginate synthesis and the prospects for management of chronic infections in cystic fibrosis. Mol. Microbiol. doi:10.1111/j.1365-2958.2005.04552.x

Reen, F.J., Gutiérrez-Barranquero, J.A., Parages, M.L., O’Gara, F., 2018. Coumarin: a novel 
player in microbial quorum sensing and biofilm formation inhibition. Appl. Microbiol. Biotechnol. doi:10.1007/s00253-018-8787-x

Rehm, B.H.A., 2010. Bacterial polymers: Biosynthesis, modifications and applications. Nat. Rev. Microbiol. doi:10.1038/nrmicro2354

Remminghorst, U., Rehm, B.H.A., 2006. Bacterial alginates: From biosynthesis to applications. Biotechnol. Lett. doi:10.1007/s10529-006-9156-x

Rendueles, O., Kaplan, J.B., Ghigo, J.M., 2013. Antibiofilm polysaccharides. Environ. Microbiol. doi:10.1111/j.1462-2920.2012.02810.x

Römling, U., Balsalobre, C., 2012. Biofilm infections, their resilience to therapy and innovative treatment strategies. J. Intern. Med. 272, 541-561. doi:10.1111/joim.12004

Römling, U., Kjelleberg, S., Normark, S., Nyman, L., Uhlin, B.E., Åkerlund, B., 2014. Microbial biofilm formation: A need to act. J. Intern. Med. doi:10.1111/joim.12242

Russo, T.A., Beanan, J.M., Olson, R., MacDonald, U., Luke, N.R., Gill, S.R., Campagnari, A.A., 2008. Rat pneumonia and soft-tissue infection models for the study of Acinetobacter baumannii biology. Infect. Immun. doi:10.1128/IAI.00269-08

Sardar, R.K., Kavita, K., Jha, B., 2015. Lipopolysaccharide of Marinobacter litoralis inhibits swarming motility and biofilm formation in Pseudomonas aeruginosa PA01. Carbohydr. Polym. doi:10.1016/j.carbpol.2015.01.045

Sawkins, M.J., Mistry, P., Brown, B.N., Shakesheff, K.M., Bonassar, L.J., Yang, J., 2015. Cell and protein compatible 3D bioprinting of mechanically strong constructs for bone repair. Biofabrication 7, 035004. doi:10.1088/1758-5090/7/3/035004

Schaffner, M., Rühs, P.A., Coulter, F., Kilcher, S., Studart, A.R., 2017. 3D printing of bacteria into functional complex materials. Sci. Adv. doi:10.1126/sciadv.aao6804

Schmid, J., 2018. Recent insights in microbial exopolysaccharide biosynthesis and engineering strategies. Curr. Opin. Biotechnol. doi:10.1016/j.copbio.2018.01.005

Shi, L., Hu, Y., Ullah, M.W., Ullah, I., Ou, H., Zhang, W., Xiong, L., Zhang, X., 2019. Cryogenic free-form extrusion bioprinting of decellularized small intestinal submucosa for potential applications in skin tissue engineering. Biofabrication. doi:10.1088/17585090/ab15a9

Shi, P., Tan, Y.S.E., Yeong, W.Y., Li, H.Y., Laude, A., 2018. A bilayer photoreceptor-retinal tissue model with gradient cell density design: A study of microvalve-based bioprinting. J. Tissue Eng. Regen. Med. doi:10.1002/term.2661

Silva-Correia, J., Oliveira, J.M., Caridade, S.G., Oliveira, J.T., Sousa, R.A., Mano, J.F., Reis, R.L., 2011. Gellan gum-based hydrogels for intervertebral disc tissue-engineering applications. J. Tissue Eng. Regen. Med. doi:10.1002/term.363

Silva Santos, K., Barbosa, A.M., Da Costa, L.P., Pinheiro, M.S., Oliveira, M.B.P.P., Ferreira Padilha, F., 2016. Silver nanocomposite biosynthesis: Antibacterial activity against multidrug-resistant strains of Pseudomonas aeruginosa and Acinetobacter baumannii. Molecules. doi:10.3390/molecules21091255

Singh, S., Lohani, A., Mishra, A.K., Verma, A., 2019. Formulation and evaluation of carrot seed oil-based cosmetic emulsions. J. Cosmet. Laser Ther. doi:10.1080/14764172.2018.1469769

Skardal, A., Devarasetty, M., Kang, H.W., Mead, I., Bishop, C., Shupe, T., Lee, S.J., Jackson, J., Yoo, J., Soker, S., Atala, A., 2015. A hydrogel bioink toolkit for mimicking native tissue biochemical and mechanical properties in bioprinted tissue constructs. Acta Biomater. 25, 24-34. doi:10.1016/j.actbio.2015.07.030

Skardal, A., Zhang, J., Prestwich, G.D., 2010. Bioprinting vessel-like constructs using 
hyaluronan hydrogels crosslinked with tetrahedral polyethylene glycol tetracrylates. Biomaterials 31, 6173-6181. doi:10.1016/j.biomaterials.2010.04.045

Smith, A.M., Shelton, R.M., Perrie, Y., Harris, J.J., 2007. An initial evaluation of gellan gum as a material for tissue engineering applications. J. Biomater. Appl. doi:10.1177/0885328207076522

Spanò, A., Laganà, P., Visalli, G., Maugeri, T.L., Gugliandolo, C., 2016. In Vitro Antibiofilm Activity of an Exopolysaccharide from the Marine Thermophilic Bacillus licheniformis T14. Curr. Microbiol. doi:10.1007/s00284-015-0981-9

Sugumaran, K.R., V, P., 2017. Review on production, downstream processing and characterization of microbial pullulan. Carbohydr. Polym. doi:10.1016/j.carbpol.2017.06.022

Sulaeva, I., Henniges, U., Rosenau, T., Potthast, A., 2015. Bacterial cellulose as a material for wound treatment: Properties and modifications: A review. Biotechnol. Adv. 33, 1547-1571. doi:10.1016/j.biotechad v.2015.07.009

Sun, G., Zhang, X., Shen, Y.-I., Sebastian, R., Dickinson, L.E., Fox-Talbot, K., Reinblatt, M., Steenbergen, C., Harmon, J.W., Gerecht, S., 2011. Dextran hydrogel scaffolds enhance angiogenic responses and promote complete skin regeneration during burn wound healing. Proc. Natl. Acad. Sci. doi:10.1073/pnas.1115973108

Sze, J.H., Brownlie, J.C., Love, C.A., 2016. Biotechnological production of hyaluronic acid: a mini review. 3 Biotech. doi:10.1007/s13205-016-0379-9

Travier, L., Rendueles, O., Ferrières, L., Herry, J.M., Ghigo, J.M., 2013. Escherichia coli resistance to nonbiocidal antibiofilm polysaccharides is rare and mediated by multiple mutations leading to surface physicochemical modifications. Antimicrob. Agents Chemother. doi:10.1128/AAC.02606-12

Trombetta, R., Inzana, J.A., Schwarz, E.M., Kates, S.L., Awad, H.A., 2017. 3D Printing of Calcium Phosphate Ceramics for Bone Tissue Engineering and Drug Delivery. Ann. Biomed. Eng. 45, 23-44. doi:10.1007/s10439-016-1678-3

Tshikantwa, T.S., Ullah, M.W., He, F., Yang, G., 2018. Current Trends and Potential Applications of Microbial Interactions for Human Welfare. Front. Microbiol 9, 1156. doi:10.3389/fmicb.2018.01156

Tumbleston, J.R., Shirvanyants, D., Ermoshkin, N., Janusziewicz, R., Johnson, A.R., Kelly, D., Chen, K., Pinschmidt, R., Rolland, J.P., Ermoshkin, A., Samulski, E.T., DeSimone, J.M., 2015. Continuous liquid interface production of 3D objects. Science (80-. ). 347, 13491352. doi:10.1126/science. aaa2397

Tytgat, H.L.P., Lebeer, S., 2014. The Sweet Tooth of Bacteria: Common Themes in Bacterial Glycoconjugates. Microbiol. Mol. Biol. Rev. doi:10.1128/mmbr.00007-14

Ul-Islam, M., Khan, S., Khattak, W.A., Ullah, M.W., Park, J.K., 2015. Synthesis, chemistry, and medical application of bacterial cellulose nanocomposites, Advanced Structured Materials. doi:10.1007/978-81-322-2473-0_13

Ul-Islam, M., Khan, S., Ullah, M.W., Park, J.K., 2019a. Comparative study of plant and bacterial cellulose pellicles regenerated from dissolved states. Int. J. Biol. Macromol. 137, 247-252. doi:10.1016/j.ijbiomac.2019.06.232

Ul-Islam, M., Khattak, W.A., Ullah, M.W., Khan, S., Park, J.K., 2014. Synthesis of regenerated bacterial cellulose-zinc oxide nanocomposite films for biomedical applications. Cellulose 21, 433-447. doi:10.1007/s10570-013-0109-y

Ul-Islam, M., Shah, N., Ha, J.H., Park, J.K., 2011. Effect of chitosan penetration on physico- 
chemical and mechanical properties of bacterial cellulose. Korean J. Chem. Eng. 28, 17361743. doi:10.1007/s11814-011-0042-4

Ul-Islam, M., Subhan, F., Islam, S.U., Khan, S., Shah, N., Manan, S., Ullah, M.W., Yang, G., 2019b. Development of three-dimensional bacterial cellulose/chitosan scaffolds: Analysis of cell-scaffold interaction for potential application in the diagnosis of ovarian cancer. Int. J. Biol. Macromol. 137, 1050-1059. doi:10.1016/j.ijbiomac.2019.07.050

Ullah, M.W., Ul-Islam, M., Khan, S., Kim, Y., Jang, J.H., Park, J.K., 2016a. In situ synthesis of a bio-cellulose/titanium dioxide nanocomposite by using a cell-free system. RSC Adv. 6, 22424-22435. doi:10.1039/c5ra26704h

Ullah, M.W., Ul-Islam, M., Khan, S., Kim, Y., Park, J.K., 2016b. Structural and physicomechanical characterization of bio-cellulose produced by a cell-free system. Carbohydr. Polym. doi:10.1016/j.carbpol.2015.10.010

Ullah, M.W., Ul Islam, M., Khan, S., Shah, N., Park, J.K., 2017. Recent advancements in bioreactions of cellular and cell-free systems: A study of bacterial cellulose as a model. Korean J. Chem. Eng. 34, 1591-1599. doi:10.1007/s11814-017-0121-2

Valle, J., Da Re, S., Henry, M., Fontaine, T., Balestrino, D., Latour-Lambert, P., Ghigo, J.M., 2006. Broad-spectrum biofilm inhibition by a secreted bacterial polysaccharide. Proc. Natl. Acad. Sci. U. S. A. doi:10.1073/pnas.0605399103

Visser, J., Melchels, F.P.W., Jeon, J.E., van Bussel, E.M., Kimpton, L.S., Byrne, H.M., Dhert, W.J.A., Dalton, P.D., Hutmacher, D.W., Malda, J., 2015. Reinforcement of hydrogels using three-dimensionally printed microfibres. Nat. Commun. 6, 6933. doi:10.1038/ncomms7933

Wang, J., Zhao, X., Yang, Y., Zhao, A., Yang, Z., 2015. Characterization and bioactivities of an exopolysaccharide produced by Lactobacillus plantarum YW32. Int. J. Biol. Macromol. doi:10.1016/j.ijbiomac.2014.12.006

Wang, Z., Abdulla, R., Parker, B., Samanipour, R., Ghosh, S., Kim, K., 2015. A simple and high-resolution stereolithography-based 3D bioprinting system using visible light crosslinkable bioinks. Biofabrication 7, 045009. doi:10.1088/1758-5090/7/4/045009

Widner, B., Dollen, S. Von, Tang, M., Heu, T., Sloma, A., Sternberg, D., Deangelis, P.L., Weigel, P.H., Brown, S., 2005. Hyaluronic Acid Production in Bacillus subtilis. Appl. Environ. Microbiol. doi:10.1128/AEM.71.7.3747

Wu, S., Liu, G., Jin, W., Xiu, P., Sun, C., 2016. Antibiofilm and anti-infection of a marine bacterial exopolysaccharide against Pseudomonas aeruginosa. Front. Microbiol. doi:10.3389/fmicb.2016.00102

Xu, T., Zhao, W., Zhu, J.M., Albanna, M.Z., Yoo, J.J., Atala, A., 2013. Complex heterogeneous tissue constructs containing multiple cell types prepared by inkjet printing technology. Biomaterials. doi:10.1016/j.biomaterials.2012.09.035

Yi, H.G., Lee, H., Cho, D.W., 2017. 3D printing of organs-on-chips. Bioengineering. doi:10.3390/bioengineering4010010

Yu, C., Ma, X., Zhu, W., Wang, P., Miller, K.L., Stupin, J., Koroleva-Maharajh, A., Hairabedian, A., Chen, S., 2019. Scanningless and continuous 3D bioprinting of human tissues with decellularized extracellular matrix. Biomaterials. doi:10.1016/j.biomaterials.2018.12.009

Yu, I., Kaonis, S., Chen, R., 2017. A Study on Degradation Behavior of 3D Printed Gellan Gum Scaffolds, in: Procedia CIRP. doi:10.1016/j.procir.2017.04.020

Yu, Y., Zhang, Y., Ozbolat, I.T., 2014. A Hybrid Bioprinting Approach for Scale-Up Tissue Fabrication. J. Manuf. Sci. Eng. 136, 061013. doi:10.1115/1.4028511 
Yue, J., Zhao, P., Gerasimov, J.Y., Van De Lagemaat, M., Grotenhuis, A., Rustema-Abbing, M., Van Der Mei, H.C., Busscher, H.J., Herrmann, A., Ren, Y., 2015. 3D-Printable Antimicrobial Composite Resins. Adv. Funct. Mater. doi:10.1002/adfm.201502384

Yue, K., Trujillo-de Santiago, G., Alvarez, M.M., Tamayol, A., Annabi, N., Khademhosseini, A., 2015. Synthesis, properties, and biomedical applications of gelatin methacryloyl (GelMA) hydrogels. Biomaterials 73, 254-271. doi:10.1016/j.biomaterials.2015.08.045

Zhang, W., Ullah, I., Shi, L., Zhang, Y., Ou, H., Zhou, J., Ullah, M.W., Zhang, X., Li, W., 2019. Fabrication and characterization of porous polycaprolactone scaffold via extrusion-based cryogenic 3D printing for tissue engineering. Mater. Des. 180, 107946. doi:10.1016/j.matdes.2019.107946

Zimmermann, U., Klöck, G., Federlin, K., Hannig, K., Kowalski, M., Bretzel, R.G., Horcher, A., Entenmann, H., Sieber, U., Zekorn, T., 1992. Production of mitogen-contamination free alginates with variable ratios of mannuronic acid to guluronic acid by free flow electrophoresis. Electrophoresis. doi:10.1002/elps.1150130156 
Fig. 1. Bioprinting Technologies: Extrusion-based bioprinting uses pneumatic and mechanical force to dispense the bioink. The bioink is extruded as a continuous filament by one of three techniques, (a) pneumatic pressure, (b) mechanical piston, and (c) rotating screw. Droplet/inkjet bioprinting enables accurate ink deposition with droplets generated by thermal (d), or piezoelectric (e) techniques. The bioink is generated by a short electric pulse to the heating element, forming a bubble, which exudes the ink droplet onto the substrate. Similarly, a droplet is formed when a charge is applied to piezo crystals in the piezoelectric inkjets, the resulting vibration forces out the ink droplet. Laser-assisted bioprinting deposits an individual cell with a laser pulse from a donor bioink coated source layer. The laser pulse creates a bubble in the energy-absorbing layer, forcing the cells in the donor layer to be deposited to the substrate enabling nozzle-free, high-resolution precision printing with more viscous bioinks. Stereolithography polymerizes photosensitive polymers (resin). An XY digital scanner and mirror array focuses UV light onto the platform. As each surface layer is polymerized, the platform drops allowing the resin to wash over the print. The UV light then polymerizes this new layer. This cycle continues until the object is printed. 
Fig. 2. Cellulose Hydrogels: Schematic illustration of (A) synthesis of $\beta$-1,4-glucan chains and their excretion from the bacterial cells across the cell wall through TCs, involving the (B) synthesis and aggregation of fibrils, (C) formation of pellicles, (D) movement of pellicle towards the air-medium interface due to density gradient (cell-free system), and (E) and formation of BC sheet at air-medium interface in the form of a $(\mathrm{F})$ hydrogel, which is seen as a $(\mathrm{G})$ reticulated fibrous structure forming a network of cellulose fibres. The figure has been adapted from (UlIslam et al., 2015; Kim et al., 2019). 


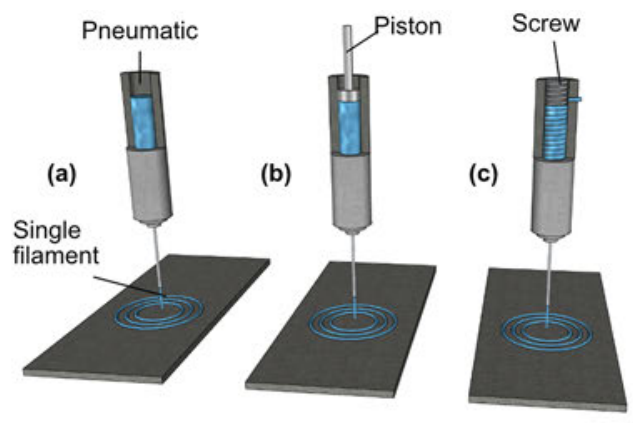

Extrusion Bioprinting
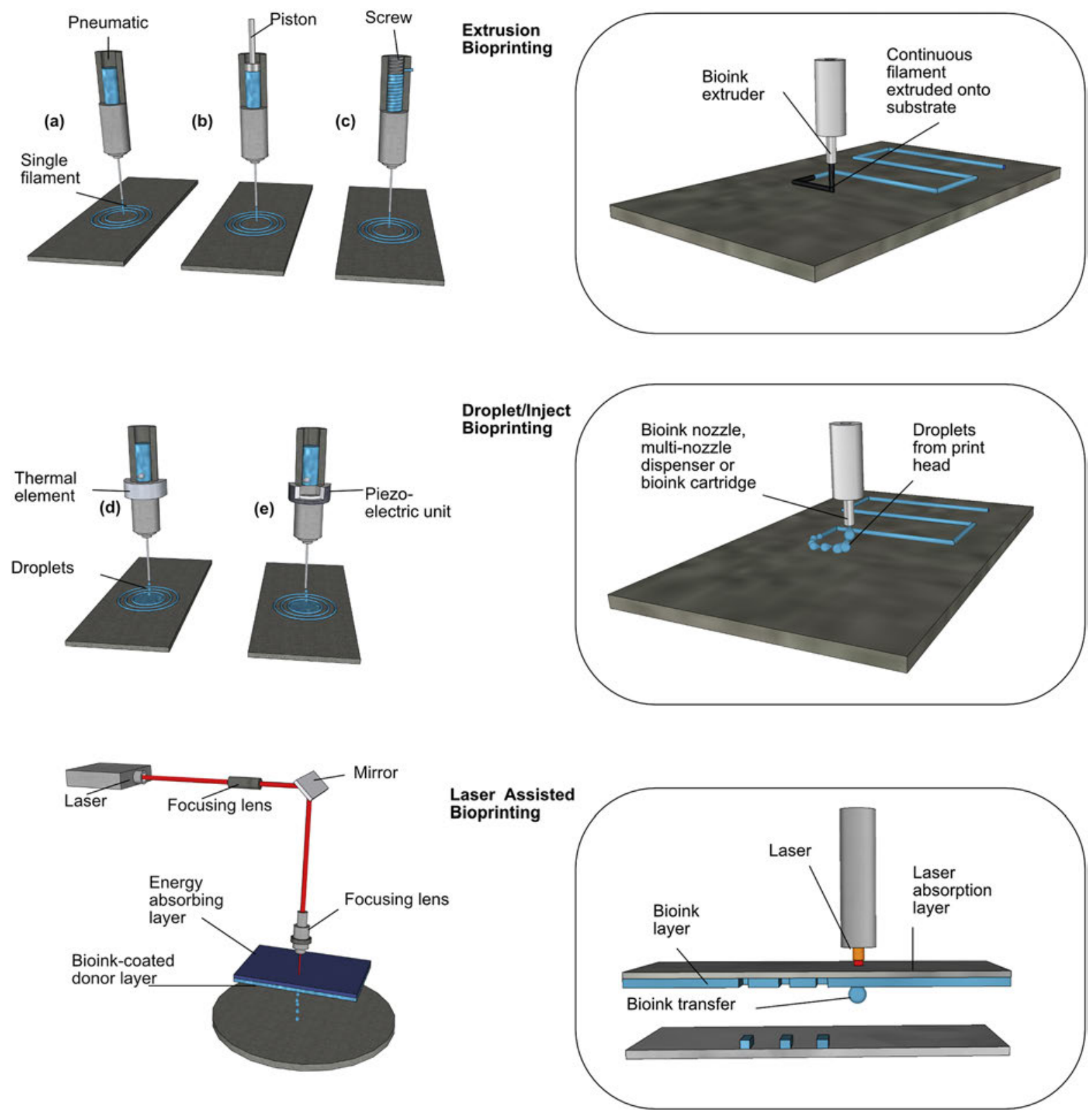

\section{Stereolithography}

Bioprinting
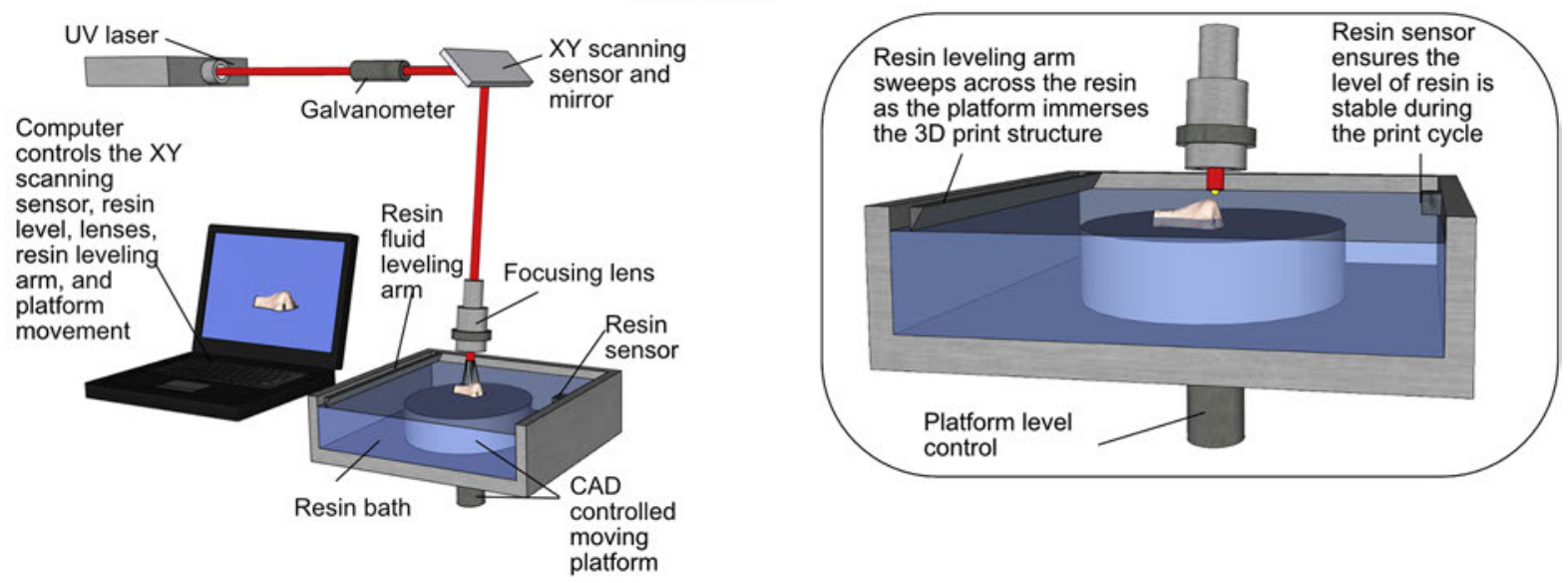

Figure 1 


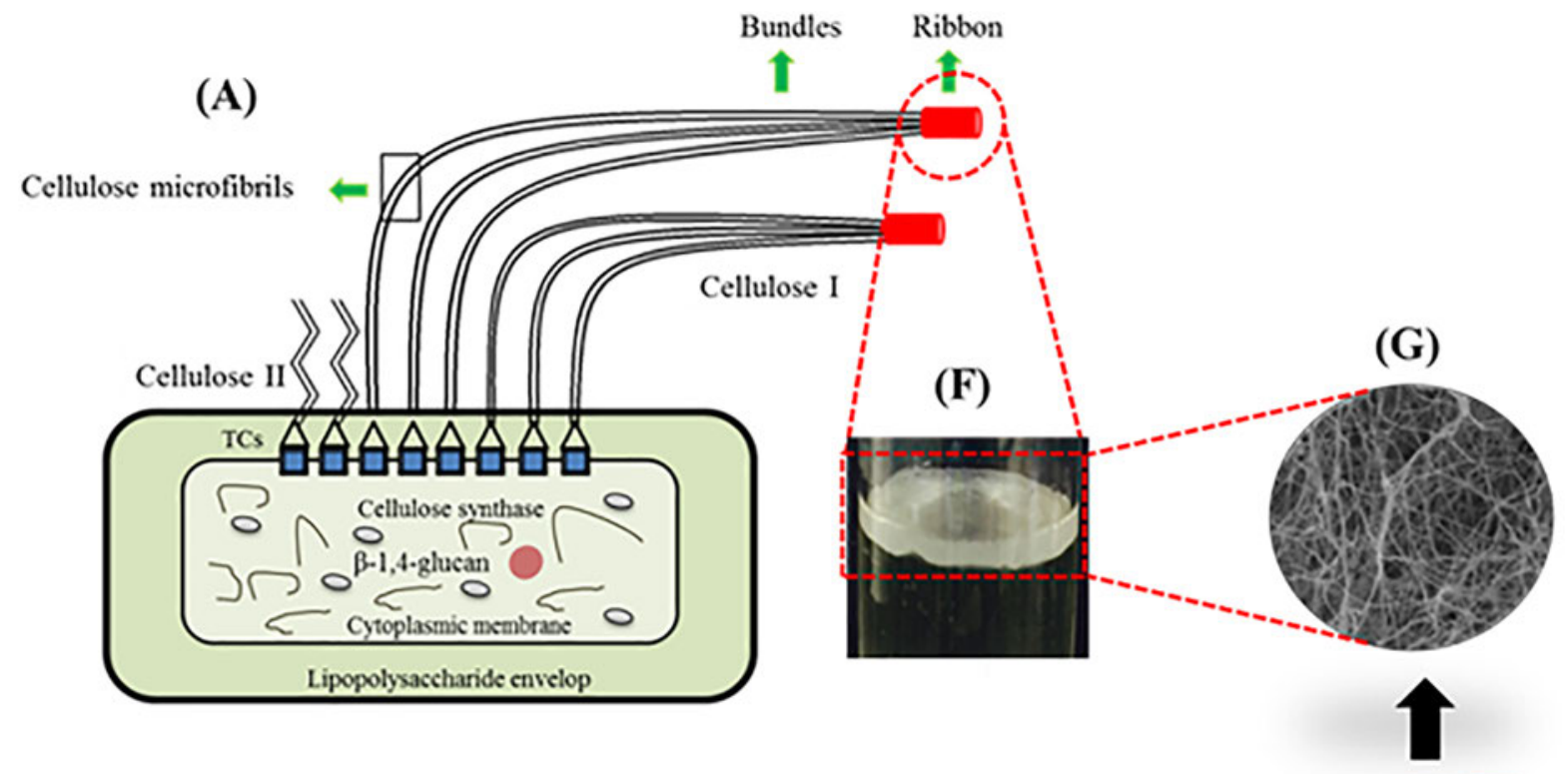

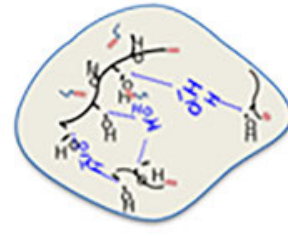

(B)

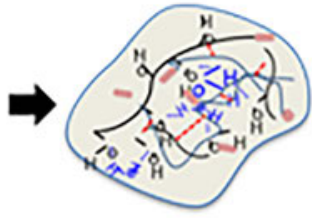

(C)
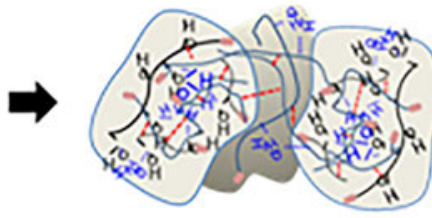

(D)

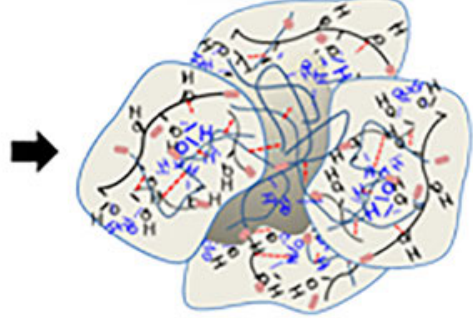

(E)

Figure 2 